\title{
Marian Przybyłko
}

\section{Urząd dziekana w rozwoju historycznym}

Prawo Kanoniczne : kwartalnik prawno-historyczny 5/1-2, 77-148

1962

Artykuł został zdigitalizowany i opracowany do udostępnienia w internecie przez Muzeum Historii Polski w ramach prac podejmowanych na rzecz zapewnienia otwartego, powszechnego i trwałego dostępu do polskiego dorobku naukowego i kulturalnego. Artykuł jest umieszczony w kolekcji cyfrowej bazhum.muzhp.pl, gromadzącej zawartość polskich czasopism humanistycznych i społecznych.

Tekst jest udostępniony do wykorzystania w ramach dozwolonego użytku. 


\title{
KS. MARIAN P R Z Y B Y L K O
}

\section{URZĄD DZIEKANA W ROZWOJU HISTORYCZNYM *}

\author{
ROZDZIAE V
}

\section{Archiprezbiterzy}

1. Archiprezbiterzy $w$ powszechnym prawie kościelnym

A. Archiprezbiter jednostkowy

a. Powstanie urzędu

Termin ,archiprezbiter" jest pochodzenia greckiego. Pojawił się prawie jednocześnie z tytułem archidiakona. Powszechne prawo obywatelstwa w literaturze kościelnej uzyskał już w początkach $\mathrm{V}$ w. ${ }^{370}$. W Kościele zachodnim został przyjęty

* Zob. początek niniejszej pracy: Prawo Kanoniczne, R. 1960, Nr 3-4, s. 195 .

${ }^{370}$ Sw. Grzegorz z Nazjanzu (um. 390) używa tu jeszcze terminu „pierwszy", lub „znaczniejszy kapłan”, jak świadczy np. jego Oratio $\$ 3$ in laudem Basilii Magni, c. 39. M i g n e P. G., t. 36, kol. 550. Koło r. 411 św: Hieronim, jak również historycy kościelni w osobach Sozomena i Sokratesa, na oznaczenie głównego kapłana $z$ otoczenia biskupa stosują wyraz ,archipresbyter". Por. np. św. Hieronim, Epist. 125, c. 15. Mig n e, P. L., t. 22, kol. 1080.; Sozom e n u s, Historia eccl., lib. 8, c. 12. Mi i n e, P. G., t. 67, kol. 1546.; Socrates, Hist. eccl., lib. 6, c. 9. Migne, P. G., t. $67, \mathrm{kol} .691$. - W świetle przytoczonych cytat staje się bardziej zrozumiałe następujace zdanie autora Iuris ecclesiastici analysis. Pars. prior. Vratislawiae 1795. Typis Universitatis, s. 110: "Archipresbyteri: hi seniores olim reliquorum erant presbyterorum, hoc nomine jam a saec. IV compellati". 
na oznaczenie pierwszego w godności kapłana spośród t. zw. prezbiterium biskupiego. $\mathrm{Na}$ wschodzie odpowiadał $\mathrm{mu}$ tytuł protoprezbitera, lub w okresie późniejszym protopapy ${ }^{371}$.

Oczywiście, jak zauważa Amanieu $\mathbf{3 7 2}$ postać archiprezbitera ukazała się o wiele wcześniej, niż otrzymała odpowiednią na$z$ wę. Jest rzeczą aż nazbyt zrozumiałą, że w chwili, gdy grono kapłanów, będących pomocnikami biskupa i stanowiących jego przyboczną radę, odpowiednio wzrosło, co stać się musiało zapewne już w czasie pierwszego, znanego nam rozkwitu Kościoła, tj. w latach $275-303^{373}$, jeden spośród nich, najprawdopodobniej najstarszy święceniami ${ }^{374}$, zaczął się wybijać na plan pierwszy, dając początek instytucji archiprezbiteratu w ogóle, a w szczególności archiprezbiteratu biskupiego, czyli miejskiego, tak później znanego $\mathrm{W}$ praktyce ${ }^{375}$ i nawet prawem nakazanego ${ }^{376}$.

Pierwotnie nie miał on żadnych uprawnień w stosunku do pozostałych konfratrów, lecz jedynie pewne stanowisko honorowe, oparte na pierwszeństwie święceń i formalnie zatwierdzane ze strony biskupa. Z czasem jednak, mianowicie już w w. $V$, a nawet i wcześniej ${ }^{377}$, uprawnienia archiprezbitera wzrastają. Przysługiwać mu będzie nie tylko pierwszeństwo honorowe wobec pozostałego kleru, lecz również pewna w sto-

371 Encykl. Kość. Nowodworskiego, t. 1, s. 373, sv. Archiprezbiter; Iuris ecclesiastici analysis. Pars prior, s. 111; oraz $\mathrm{T}$ hom as in $\mathrm{m}$ s L., dz. c., t. 1, ks. 2, s. 13 .

sĩ Podręczna Encykl. Kość., t. 1-2, s. 312. Archipresbyter.

373 Zob. wyżej odn. 50.

374 Thom assinus L., dz. c., t. 1, ks. 2, s, 13, A manieu A., Archiprêtre. Dictionnaire de droit canonique ...publié sous la direction de R. Naz Paris - VI 1935, t. 1, kol. 1004, oraz niżej odn. 379, gdzie zacytowany jest list papieża Leona I do biskupa Benewentu i fragment kazania św. Grzegorza z Nazjanzu, przyt. w odn. 370 .

${ }_{375}$ Por. np. list św. Hieronima do Rusticusa, przytoczony w odn. 370 , jak również list papieża Leona I do biskupa Benewentu $z$ odn. 379 .

${ }_{376}$ Syn. emerytański (conc. Emeritense) z r. 666, c. 10. M a n s i, t. 11, kol. 81.

377 Amanieu A., Archiprêtre. Dictionnaire de droit canonique, t. 1, kol. 1004 . 
sunku do niego władza oraz możność sprawowania całego szeregu czynności ${ }^{378}$.

Zjawisku temu towarzyszyło zwiększanie się wpływu biskupa na jego nominację. Ponieważ praktyka wykazała, że nie zawsze najstarszy święceniami kapłan umiał należycie wywiązywać się $\mathrm{z}$ obowiązków związanych $\mathrm{z}$ tak wysokim $w$ diecezji stanowiskiem, niektórzy z biskupów zaczęli na stanowisko archiprezbitera wynosić kapłana najbardziej godnego i uzdolnionego, bez oglądania się na datę jego wyświęcenia. Wypadki takie częściej można było widzieć na Wschodzie, niż w Kościele łacińskim, gdyż tu naruszanie tradycji wywoływało silne niezadowolenie wśród zainteresowanego duchowieństwa. i. ściągało naganę papieży, nakazujących zachowywanie dawnych zwyczajów ${ }^{379}$. Wpływ zaś prezbiterium kapłańskiego na wybór archiprezbitera był tak silny, iż bez jego zezwolenia biskup nie mógł tego dostojnika usuwać, choćby ten $\mathrm{w}$ swoich obowiązkach bardzo się zaniedbał ${ }^{380}$.

\section{b. Uprawnienia}

Jaką archiprezbiter $\mathrm{w}$ pierwszej fazie swego istnienia posiadał władzę, a w szczególności jaki był jego stosunek do drugiego dostojnika $w$ diecezji, tj. archidiakona, trudno cośkolwiek powiedzieć z braku odpowiednich źródeł ${ }^{381}$. Wpraw-

${ }_{378} \mathrm{Kur}$ tscheid B., Historia iuris canonici. Historia institutionum. Romae 1941, t. 1, s. 166, A man i e u A., Archiprêtre. Tamże.

379 Por. np. Encykl. Kość. Nowodworskiego, t. 1, s. 374, sv. Archiprezbiter; Thomassinus L., dz. c., t. 1, ks. 2, s. 13; oraz np. list Leona I, papieża (r. 440-461), đo biskupa Benewentu p. 19. Migne, P. L., t. 54, kol. 710.- Na wschodzie, w epoce wcześniejszej dziejów archiprezbiteratu, również było żywe poczucie tradycji, jak tego każe się domyślać przytoczony wyżej w odn. 370 fragment kazania św. Grzegorza z Nazjanzu.

380 Conc. Turonense II (r. 567), c. 7. M a n si, t. 9, kol. 793.

381 Zob. o tym Kurtscheid B., dz. c., t. 1, s. 165, oraz Amanieu A., Archiprêtre. j. w. t. 1., kol. 1004-1005. 
dzie na początku $V$ w. św. Hieronim ${ }^{382}$, w przeszło zaś dwa wieki później za nim, synod emerytański ${ }^{883}$, wyliczając godności kościelne, szeregują je w sposób następujący: biskup, archiprezbiter i archidiakon, ale najprawdopodobniej mają na myśli nie porządek władzy, lecz porządek oparty na powadze święceń, który w praktyce $\mathrm{z}$ biegiem lat coraz bardziej od poprzedniego się różnił. Jak wiemy skądinąd ${ }^{384}$, już od V w. w zarządzie diecezją można zauważyć przewagę archidiakona, który szczególnie w w. IX odnosi nad swoim kolegą całkowite zwycięstwo. Pochodzący z tego okresu list Pseudo-Izydora nie pozostawia pod tym względem żadnych wątpliwości. „Archiprezbiter - tak brzmia jego słowa - niech pamięta, że jest pod władzą archidiakona i ma słuchać jego nakazów, tak jakby pochodziły od samego biskupa" ${ }^{385}$.

W wyniku opisanego stanu rzeczy archiprezbiter musiał sic zamknąc $\mathrm{w}$ dziedzinie spraw czysto kapłańskich i duchowych, cały zewnętrzny zarząd diecezji, oczywiście w zależnósici od biskupa, pozostawiając w ręku swego niższego święceniami konkurenta.

Prawa i obowiązki archiprezbitera tak w świetle wspomnianego listu Pseudo-Izydora, zalecającego się i bogactwem treści i starożytnością ${ }^{386}$, co zapewne skłoniło Gracjana ${ }^{387}$

382 Zob. odn. 370 .

383 Zob. odn. 376.

384 Zob. odn. 128, 133 i 247; jak również A m a n i e u A., Archiprétre. Tamże.

385 Oryginalny tekst łaciński tego listu przytacza c. $1, \S 12$, D. 25 oraz np. Thom assinus L., dz. c., t. 1, ks. 2, s. 132. Por. o tym odn. 128.

386 Por. np. Amanieu A., Archiprêtre, jw. kol. 1005.- Z listu Pseudo-Izydora dla omawianej sprawy ma znaczenie nie tylko tekst, przytoczony $w$ odn. 128 , ale również $i$ to miejsce, gdzie jest mowa o czynnościach kapłańskich, nad którymi przecież archiprezbiter miał czuwać. Do tych czynności, według c. $1, \S 8$, D. 25, należą: „Ad presbyterum pertinet sacramentum corporis et sanguinus Domini in altare Dei conficere, orationes dicere; et benedicere dona Dei".

387 Wyjątki z listu Pseudo-Izydora w ujęciu Gracjana, odnoszące się do zagadnienia archiprezbitera, zob. w odn. 128 i 386. 
i Grzegorza IX ${ }^{388}$ do umieszczenia go w swoich Zbiorach, jak również według tychże Dekretałów, które poszły po linii jego wyjaśnień i uzupełnień ${ }^{389}$, przedstawiając się następująco:

1. Czuwa on nad sposobem odprawiania służby bożej i zachowaniem przepisów liturgicznych przez całe duchowieństwo $w$ stolicy biskupiej, zwłaszcza w odniesieniu do mszy św. i godzin kanonicznych ${ }^{390}$.

2. W czasie uroczystej celebry biskupiej baczy, by asystujący pasterzowi kler był przybrany $\mathrm{w}$ odpowiednie szaty na oznaczoną godzinę i zachowywał należyty porządek przy wychodzeniu do ołtarza ${ }^{391}$.

3. Do niego należy troska, czy w kościołach stolicy biskupiej znajduje się dostateczna ilość konsekrowanych komunikantów, potrzebnych do zaopatrywania chorych i umierających oraz czy kapłani związane $z$ tym posługi należycie spełniają ${ }^{392}$.

4. Jako główny penitencjariusz, w trudniejszych wypadkach rozgrzesza i jedna $z$ Kościołem pokutujących tak cywilnych, jak i księży, dla których jest zwykłym spowiednikiem, i zarazem czuwa nad właściwym administrowaniem sakramentu spowiedzi przez miejscowe duchowieństwo ${ }^{393}$.

5. On wreszcie pilnuje, aby księża ważnie i godnie udzielali chrztu św. dzieciom i dorosłym i by tych ostatnich

388 Por. c. 1 i 2, X, de officio archiprezbyteri, I, 24. Dekretaly te prawie dosłownie powtarzają wspomniane $w$ poprzednim odnośniku wyjątki ze Zbioru Gracjana, dlatego przy omawianiu szczególowym uprawnień archiprezbitera tylko ich się trzymam.

389 C. $2, \S 1,2$ i 3 oraz c. 3 . $X$, de officio archipresbyteri, I, 24.

${ }^{390}$ C. $2, \mathrm{X}$, de officio archipresbyteri, I, 24. - Por. także B ar bos a A., Iuris ecclesiastici universi libri tres. Lugduni 1645, t. 1, s. 292, oraz $\mathrm{SchmaIzgrueber} \mathrm{F.,} \mathrm{Ius} \mathrm{ecclesiasticum} \mathrm{universum,} \mathrm{Romae} \mathrm{1844,}$ t. 1, cz. 2, s. 140 .

301 C. $3, \mathrm{X}$, de officio archipresbyteri, I, 24.

392 Tamże.

${ }_{393}$ Tamże. Por. także Schmalzgrueber F., j.w., oraz Barbos a A., dz. c., s. 293. 
odpowiednio przygotowywali do przyjęcia wiary wedłus wskazówek, jakie im nieomieszka podać ${ }^{994}$.

6. Podczas nieobecności biskupa w jego zastępstwie ma prawo i obowiązek spełniać wszystkie te czynności, które nie wymagaja posiadania sakry biskupiej, lub osobistego uczestnictwa pasterza diecezji. W szczególności winien on wtedy zwrócić baczniejszą uwage na prace duszpasterską duchowieństwa: każdy powinien być ochrzczony, jeśli tego żąda i należycie się przysposobi, przy czym archiprezbiterowi przysługuje możność uroczystego poświęcenia wody chrzcielnej; chorzy winni być zaopatrywani na drogę wieczności; pokutujący - jednani z Bogiem i Kościołem; nawet kapłani upadli - przywracani do służby przy ołtarzu, jeśli za swe winy żałują i wypełnią nałożoną sobie przez niego stosowną pokutę ${ }^{395}$.

7. Więcej, gdyby biskup wyjechał, zachorował, lub dla innej przyczyny nie mógł celebrować ${ }^{396}$, archiprezbiter może i powinien $w$ jego imieniu przewodniczyć $w$ uroczystsze święta na nabożeństwach w katedrze, udzielać błogosławieństwa zebranemu ludowi i, co najważniejsze, odprawiać pontyfikalną mszę św., czy też zlecić, by w celebrze wyręczył go kto inny ${ }^{397}$.

8. „Sede vacante" archiprezbiter wraz z archidiakonem i prymiceriuszem ${ }^{398}$ kieruje rządami diecezji i przeprowadza wybory nowego biskupa, przy czym, choć trudno bliżej określić jego stanowisko w tym cżasie, zdaje się nie ulegać wątpliwości, że rola jego w owym trium-

394 C. $3, \mathrm{X}$, de officio archipresbyteri, I, 24. A m a n i e u A., Archiprêtre, j. w., kol. 1006, widocznie rozszerza treść tego dekretału. Tak przynajmniej to wygląda $w$ świetle wyjaśniających go słów Schmaizgruebera F., j. w., s. 140 .

395 C. $2, \S 2, X$, de officio archipresbyteri, I, 24.- Por. także Schmalzgrueber F., j. w., s. 139.

396 Por. Krynicki W., dz. c., t. 1., s. 115.

${ }^{397}$ C. $2, \S 3$ i c. $3, X$, de officio archipresbyteri, I, 24. - Por. także Schmalzgrueber F., j. w. s. 139.

398 C. $1, \S 13$, D. 25.- Por. także $R$ eiffenstuel A., Ius canonicum universum. Parisis 1853, t. 1, s. 424-425. 
wiracie ze względu na święcenia kapłańskie, których obaj pozostali nie posiadali, była przodujaca. Taki przynajmniej stan rzeczy panował w Rzymie, gdzie szezegółowymi przepisami obwarowano sprawę następcy Piotrowego ${ }^{399}$.

9. Względnie krótki ten okres wskrzeszonej aktywności praktycznej archiprezbitera był tylko dalekim echem minionych wieków, kiedy to przysługiwały mu uprawnienia nie wyłącznie o charakterze duchowo-kapłańskim. Przecież synod kartagiński IV z r. 436 jemu i jego koledze, archidiakonowi, zlecal w imieniu biskupa troske o wdowy, sieroty i pielgrzymów ${ }^{400}$. Synod aureljański $\mathrm{V}$ z r. 549 nakazywal obydwom co niedziela odwiedzać więźniów i dbać, by przynajmniej głodu nie cierpieli ${ }^{401}$. On także narówni $z$ archidiakonem, na mocy zarządzenia synodu audisjordoreńskiego z r. 578, mial bronić osoby duchowne przed niesłusznymi roszczeniami ze strony świeckich ${ }^{402}$. On wreszcie, zgodnie $z$ nakazem synodu emeryteńskiego $\mathrm{z}$ r. $666, \mathrm{w}$ wypadkach koniecznych powinien reprezentować osobe swego biskupa na zjazdach, którym przewodniczy metropolita, co, mówiąc nawiasem, rzadko było praktykowane ${ }^{403}$.

10. Na koniec tam, gdzie nie znano instytucji archidiakonatu, na mocy prawa zwyczajowego wypełniał zwykłe czynności archidiakona ${ }^{404}$.

${ }^{399}$ Zob. A m an i eu A., Archiprêtre, j. w., kol. 1006, oraz tegoż autora Archidiacre, tamże, kol. 958.

400 Zob. kan. 17 tegoż synodu, cyt. w odn. 132.

401 Conc. Aurelianense V., c. 20. M a n s i, t. 9, kol. 134.- Zob. także Kurtscheid B., dz. c., t. 1, s. 165.

402 Conc. Autisiodorense z r. 578 (taką jego nazwę i rok podaje M a n si, t. 9, kol. 911-912; Kurtscheid B., dz. c., t. 1, s. 165, nazywa ten synod, conc. Altissiodor, ca. 573"), c. 43 . M a n si, t. 9, kol. $915-916$.

${ }_{403}$ Conc. Emeritense z r. 666, c. 5., Mansi, t. 11, kol. 79.

$404 \mathrm{Schmalzgrueber} \mathrm{F.,} \mathrm{dz.} \mathrm{c.,} \mathrm{t.} \mathrm{1,} \mathrm{cz.} \mathrm{2,} \mathrm{s.} \mathrm{140.} \mathrm{A} \mathrm{manieu}$ A., Archiprêtre, j. W., kol. 1007, podaje za Du Cange'em przyklad wladzy archidiakońskiej archiprezbitera. 
Wspomniane uprawnienia o charakterze administracyjno-jurysdykcyjnym przeszły z czasem prawie wyłącznie na archidiakona, władza zaś archiprezbitera objęła w imieniu biskupa całą niemal dziedzinę spraw duchowo-kapłańskich. Utarło się nawet swoiste adagium: ,archidiaconus est vicarius natus in temporalibus, et archipresbyter est vicarius natus episcopi in spiritualibus ${ }^{405 "}$ ".

Zajęcia tego ostatniego mniej się rzucały w oczy w życiu codziennym diecezji, były jednak dla spraw wewnętrznych Kościoła bardzo doniosłe. One wysuwały go na czoło duchowieństwa i zapewniały mu wśród niego pierwszeństwo honorowe oraz pewien stopień władzy. To wystarczało, by po biskupie i archidiakonie stanowił w diecezji najważniejszą osobę, jako prawdziwy jej dygnitarz ${ }^{406}$.

\section{c. Ograniczenie władzy}

Dalsze losy archiprezbitera zawisły od szeregu czynników tak dawnych, jak i nowych. Mianowicie pojawiają się i to dość wcześnie ${ }^{407}$ archiprezbiterzy wiejscy, którzy przejmuja przysługująca pieczę nad sprawowaniem służby bożej przez duchowieństwo prowincjonalne, przez co on sam zyskuje tytuł archiprezbitera, lub dziekana miejskiego przy kościele katedralnym, czy téz kolegiackim ${ }^{408}$.

Dawny jego rywal, archidiakon, zaczyna przyjmować święcenia kapłańskie ${ }^{409}$ i zastẹpować go w spełnianiu funkcji

405 Ferraris F. L., Bibliotheca. Romea 1885, t. 1, s. 401. Zob. także Schmalzgrueber F., dz. c., t. 1, cz. 2, s. 140, oraz B a rbos a A., dz. c., t. 1, s. 293 .

${ }_{406}$ Por. odn. 492, a zwlaszcza Schm a lzgrueber F., j. W., s. 140 , oraz B a r bos a A., j. w., s. 290.

407 Zob. niżej o tym.

408 Por. np. Schmalzgrueber F., dz. c., t. 1, cz. 2, s. 139.

400 Zob. odn. 139. 
liturgicznych podczas nieobecności biskupa, początkowo ze zwyczaju, a później nawet na mocy prawa ${ }^{410}$.

Gdy w w. X-XIII obaj wejdą do kapituł, w tym okresie zyskujących samodzielność majątkowo-prawną, i tu lepiej powiedzie się archidiakonowi, który na ogól zajmie $w$ nich pierwsze miejsce, jemu zaś pozostawi drugie ${ }^{411}$, owszem, spowoduje na swoją korzyść dalszy wylom $w$ pozostałych przy nim uprawnieniach ${ }^{412}$. Jeśli gdzie zajdzie wypadek odwrotny ${ }^{413}$, to znajdą się znowu kapituły zupełnie nie uznające stanowiska archiprezbitera ${ }^{414}$.

Jednocześnie robił swoje zwyczaj często dla niego nieprzychylny, np. w sprawie spowiedzi kapłanów, którzy niekoniecznie mogli się przed nim spowiadać. Z polecenia soboru trydenckiego wprowadzono nawet umyślnego penitencjariusza przy katedrach, majacego władzę rozgrzeszania w wypadkach zarezerwowanych biskupowi ${ }^{415}$.

Pojawiający się nowy urzędnik biskupi, wikariusz generalny, również nie zaniedba przejąć pewnych funkcji, które na mocy prawa dotąd przysługiwały archiprezbiterowi ${ }^{416}$.

Tak więc powoli ten ostatni schodzi do roli zwykłego kanonika kapitulnego. Dzisiaj jego obowiązki spełnia częściowo dziekan kapituły, częściowo zaś biskup sufragan ${ }^{417}$. Jedynie tytuł proboszcza, jaki zwykle uzyska przy katedrze, lub kolegiacie, świadczyć będzie o dawnej jego przeszłości i dostojeństwie ${ }^{418}$.

410 B a r bos a A., dz. c., t. 1, s. 289.

411 Por. np. A m anieu A., Archidiacre, j. w. kol. 994, oraz odn. 231.

412 Por. np. A m anieu A., Archiprêtre, j. w, kol. 1007.

${ }^{413}$ Tamże, kol. 1018. Por. także Schmalzgrueber F., dz. c., t. 1 , cz. 2, s. 139 .

414 Tamże.

415 Ses. 24, de ref., kan. 8. Zob. także odn. 393.

416 Por. B arbos a A., dz. c., t. 1, s. 293.

${ }^{417}$ Encykl. Kość. Nowodworskiego, t. 1, s. 375, sv Archiprezbiter.

418 A m anieu A., j. w., kol. 1018. 
B. Archiprezbiterzy okregowi - dziekani.

a. Powstanie urzędu i pierwotne jego uprawnienia.

Pojawienie się archiprezbiterów okręgowych było wywołane rozwojem życia kościelnego. W początkowym okresie swego istnienia Kościół zyskiwał wyznawców po znaczniejszych miastach, zwłaszcza w stolicach poszczególnych prowincji, czyli metropoliach ${ }^{419}$. Potrzeby wiernych, tworzących zorganizowaną jednostkę terytorialną, na Wschodzie już w IV w. noszącą nazwę parafii ${ }^{420}$, zaspakajał biskup z podległym sobie odpowiednim gronem duchowieństwa, które się zwiększało w miarę wzrostu liczby chrześcijan. W bardzo krótkim czasie, by sprostać wymogom chwili, biskupi wielkich miast byli zmuszeni do budowy nowych świątyń, zwanych „tituli”, i do obsadzania przy nich osobnych kapłanów ${ }^{421}$. Ci mogli spełniać tylko pewne czynności liturgiczne i w swej pracy duszpasterskiej byli uzależnieni bezpośrednio od własnego biskupa i jego archiprezbitera ${ }^{422}$, lub archidiakona ${ }^{423}$.

Odmiennie ułożyły się stosunki poza miastem biskupim. Żyjący w II w. św. Justyn (zm. 166) w swojej Apologii notuje, że chrześcijanie ze wsi, zapewne $w$ owym czasie jeszcze nie zbyt liczni i zamieszkali w niewielkiej odległości, udają się do rajbliższych miast, by tam wziąć udział $w$ niedzielnym nabożeństwie, wysłuchać nauki, wspólnie przystąpić do Stołu Pańskiego i w miarę możności złożyć ofiare na sieroty i biednych ${ }^{424}$.

419 Por. Krynicki W., dz. c., t. 1, s. 50.

${ }_{420} \mathrm{Kurtscheid}$ B., dz. c., t. 1, s. 104, oraz Amanieu A., Archiprêtre, j. w., kol. 1007.

421 Por. Krynicki W., dz. c., t. 1, s. 50, a zwłaszcza s. 116 i tam$\dot{z}$ e, odn. 1, gdzie autor robi następującą uwagę; „Liber Pontif. wspomina już o papieżu Ewaryście (97-105?), że titulos divisit presbyteris, i o Marcelim (308-309), że podzielił miasto na 25 tytułów".

422 Zob. np. Krynicki W., dz. c., t. 1, s. 116, jak również wyżej odn. $377,378,381$.

423 Por. odn. 128, $130 \mathrm{nn}$, i $381 \mathrm{nn}$.

424 Apologia I, c. 67. M i g n e, P. G., t. 6, kol. 430. 
Wkrótce jednak, gdy $\mathrm{w}$ okresie znanego nam pokoju ${ }^{426}$, a zwłaszcza po edykcie mediolańskim, ruch misyjny dotrze do zapadłych prowincji, powstanie również na wsi, oczywiście w ośrodkach większych skupisk wiernych, potrzeba budowy świątyń ${ }^{426}$. Koło ich wznoszenia zakrzątną się biskupi, zwykli wierni, znaczniejsi panowie chrześcijańscy, lub też klaszfory. Dla należytej obsługi tych kościołów już nie wystarczy przelotna wizyta wędrownych misjonarzy, przybywających z miasta biskupiego i po krótszym, czy dłuższym pobycie doń powracających, co początkowo było i konieczne i zrozumiałe ${ }^{\mathbf{4} 27}$. Przeciwnie, należało tu stworzyć mniej, lub więcej pełną, ale trwałą organizację duszpasterską, która by udostępniła wiernym spełnianie przynajmniej najbardziej koniecznych obowiązków religijnych, tak dla nich dotąd uciążliwych z powodu oddalenia od biskupich stolic. Wzgląd ten doprowadzil na Wschodzie do powstania i nadmiernego wzrostu instytucji chorepiskopów wiejskich ${ }^{428}$, w mniejszym stopniu znanych na Zachodzie ${ }^{429}$, gdyż tu troskę o duszę mieszkańców prowincji częściej zlecano niższemu duchowieństwu już w w. III ${ }^{430}$, co nawet przez papieża Leona I Wielkiego $\mathrm{w}$ połowie $\mathrm{V} w$. i w w. VII przez synod toletański XII zostało specjalnie nakazane ${ }^{431}$, na wzór zarządzeń synodu w Sardycy, już od IV w. obowiązujących w Kościele wschodnim ${ }^{432}$.

Rzecz zrozumiała, gdzie chrześcijan było niewielu, tam wystarczała obecność diakona, który $w$ wypadkach koniecznych

\footnotetext{
425 Zob. odn. 50.

426 Por. np. Kurtscheid B., dz. c., t. 1, s. 166, oraz Krynicki W., dz, c., t. 1, s. 116.

427 Byli to tzw. periodeuci, wspomniani w odn. $098 \mathrm{cz}$. I, których zob. niżej na właściwym miejscu.

$428 \mathrm{Zob}$. odn. $50 \mathrm{nn}$.

429 Zob. odn. 65a.

${ }^{430}$ Por. np. slowa św. Dionizego Aleksandryjskiego (um. 265), przytoczone przez Euzebiusza w jego Hist. eccl., lib. 7, c. 24. M i g n e, P. G., t. 20 , kol. 695 .

431 Leon I Wielki (r. 440-461), Ep. 12, c. 10. Migne, P. L. t. 54, kol. 654 .

${ }^{432}$ Zob. odn, 60.
} 
chrzcił, nauczał i udzielał Komunii św. ${ }^{483}$. Gdy jednak liczba wiernych odpowiednio wzrosła, co następowało niekiedy w bardzo krótkim czasie, wśród nich musiał zamieszkać kapłan ${ }^{434}$. Ten ${ }^{435}$ zwykle nie usuwał dotychczasowego diakona. Owszem, o ile okoliczności tego wymagały, dobierał sobie do pomocy nowych kapłanów ${ }^{431}$, z którymi opatrywał potrzeby duchowne miejscowej ludności i nad którymi sprawował pewne przełożeństwo, sam będąc zależny od swego ordynariusza.

Teren jego pracy, $z$ czasem nazwany nà wzór terytorium biskupiego parafią, a nawet diecezją, często był bardzo rozległy i nie miał ściśle określonych granic. W miare postępu chrystianizacji dalszych okolic $w$ obrębie tak pojętej parafii wyłaniała się potrzeba budowy nowych kaplic i kościołów. Osadzeni przy nich duchowni sprawowali mniej, lub więcej rozwiniętą służbę bożą, zawsze jednak, jak i poprzedni, w wykonywaniu swych czynności byli bezpośrednio uzależnieni nie od biskupa, lecz od rektora kościoła macierzystego, któremu to przełożonemu na wzór stosunków panujących w stolicy die-

433 Syn. liberytański $z r .305$ (K u r ts cheid B., dz. c., t. 1, s. 167 , nazywa go conc. Eliberitanum), kan. 77. M a n si, t. 2, kol. 18., oraz syn. awerneński I z r. 535, kan. 15. M a n s i, t. 8, kol. 862. Podobnie stosunki układały się w szczególności we Francji, o której pisze A manieu A., Archiprêtre, j. w., kol. 1008.

434 Syn. neocezarejski $z r$. 314, kan. 13. M a n si, t. 2, kol. 548,, syn. antiocheński I z r. 341, kan. 8. Tamże, kol. 1311; Syn. wazeński z r. 442, kan. 3. M a n s i, t. 6, kol. 453; sob. chalcedoński z r. 451, kan. 6. M a n si, t. 7, kol. 375; Syn. agatenski $z$ r. 506, kan. 54. Mansi, t. 3, kol. 334., Syn. tarrakoneński z r. 516, kan. 7. Tamże, kol. 542., Syn. wazeński III z r. 529, kan. 1 i 2. Tamże, kol. 726 i 727. Por. także odn. 431.

43ă O stosunkach prawnych $w$ pierwotnych parafiach wiejskich z epoki. zwanej przez niektórych epoką Merowingów, zob. Ku r ts che id B., dz. c., t. 1, s. 166-167; A m a ni e u A., Archiprètre, j. w., kol. 1008; Krynicki W., dz. c., t. 1, s. 116. Por. także np. syn. agateński z r. 506, kan. 21. M a n si, t. 8, kol. 328.; Syn. awerneński I $z r .535$, kan. 15 (przyt. w odn. 547); oraz Syn. aureliański IV $z$ r. 541, kan. 26. M a n si, t. 9, kol. 117.

436 Jak licznym musiał być niejednokrotnie kler zamieszkały $\mathrm{w}$ bezpośrednim sąsiedztwie archiprezbitera, świadczy np. syn. tarrakoneński z r. 516, kan. 7. M a n si, t. 8, Kol. 542.; oraz Syn. turoneński (Tours) II z r. 567 , kan. 19 . M a n si, t. 9, kol. 797. 
cezji, zaczęto nadawać miano archiprezbitera, oczywiście wiejskiego.

Po raz pierwszy nazwa ta pojawia sie $w$ statutach II synodu w Tours z r. $576^{437}$, by w niedługim czasie znaleźć powszechne zastosowanie. Bez obawy pomyłki przyjąć można, że tak termin, jak i sama postać archiprezbitera wiejskiego sięgają przynajmniej początku VI w.

Obowiązki i przywileje wiejskich archiprezbiterów w początkowym okresie, zwanym epoką Merowingów, przedstawiają się następująco ${ }^{438}$.

1. W swoim kóciele macierzystym archiprezbiterzy odprawiają mszę św. i inne nabożeństwa, spowiadają oraz udzielają Komunii św. Wierni $\mathrm{z}$ ich parafii, choćby posiadali u siebie kapłana, pełniącego służbę bożą w miejscowym kościółku, czy kaplicy, są obowiązani w większe święta doroczne przybyć do ich kościoła dla zodośćuczynienia swym powinnościom religijnym ${ }^{439}$.

2. Zebranemu $w$ świątyni ludowi osobiście, lub przez diakonów głoszą w niedziele i święta słowo boże ${ }^{440}$.

3. Są zwyczajnymi szafarzami sakramentu chrztu św., który, $z$ wyjątkiem wypadków koniecznych, można przyjmować jedynie w czasie uroçzystości wielkanocnych, Zielonych Świątek i św. Jana Chrzciciela ${ }^{441}$.

4. Czuwają również, by duchowni, zatrudnieni na terenie ich parafii prowadzili życie godne swego powołania. Zarazem przygotowują nowych kandydatów do stanu duchownego ${ }^{442}$.

437 Syn. turoneński $z$ r. 567, kan. 7. MI a n i, t. 9, kol. 793. Por. także Amanieu A., Archiprètre, j. w. kol. 1008.

${ }^{438} \mathrm{Kurtscheid}$ B., dz.c. s. $168-169$, oraz A m a nieu A., Archipretre, j. w, kol. 1008-1009.

439 Por. np. wspomniany wyżej w odn. 549 syn. agateński $z$ r. 506, kan. 21, oraz syn. aureliański IV z r. 541, kan. 3, M a n si, t. 9, kol. 113. 440 Por. np. syn. wazeński III z r. 529, kan. 2. Mansi, t. 8. kol. 727. 441 Por. np. syn. autisiodoreński z r. 578 (Kurtscheid B., dz. c., s. 168, konsekwentnie synod ten nazywa „,c. Altissiodor" i umieszcza go w latach 578-603), kan. 18. IM a n si, t. 9, kol. 913-914.; oraz syn. matyskoński (conc. Matisconense) II z r. 585, kan. 3, kol. 951.

${ }_{442}$ Por. np. syn. wazé́ski III z r. 529, kan. 1, IV a n s i, t. 8, kol. 726-727 . 
Ci ostatni, według zarządzenia cesarza Arkadiusza z r. 398, co później przeszło do Kodeksu Justyniana ${ }^{443}$, lecz nie było zbyt ściśle zachowywane, powinni pochodzić spośród miejscowych parafian, aby łatwiej im przyszło nawyknąc do swych przyszłych, skądinąd tak trudnych obowiązków.

5. Gdyby kto $z$ duchownych posiadających wyższe święcenia dopuścił się jakiego przestępstwa, zwłaszcza przeciwko ce libatowi, do archiprezbiterów należało donieść o tym biskupowi, lub archidiakonowi i to pod groźbą ekskomuniki ${ }^{444}$, albo zamknięcia w klasztorze ${ }^{45}$. Zaniedbujących. się $\mathrm{W}$ pracy młodych duchownych mogli karać nawet fizycznie ${ }^{446}$.

6. Oni także, przynajmniej od VII w., posiadają prawo do administrowania majątkiem kościelnym ${ }^{447}$, powstałym z różnych darowizn, jakie wierni już od w. V zaczęli czynić na rzecz swej parafii, a który początkowo całkowicie był we władzy biskupiej ${ }^{448}$. Tego majątku powinni strzec przed uroszczeniami sądów świeckich ${ }^{449}$, nie wolno im $z$ niego nic sobie przywłaszczać ${ }^{450}$, przeciwnie, winni go powiększać ${ }^{45 t}$ i dochody zeń powstałe obracać na utrzymanie całego parafialnego duchowieństwa ${ }^{452}$.

443 C. I. 3, 11. Por. także odn. 452.

${ }_{444}$ Por. np. Syn. autisjodoreński $z$ r. 578, kan. 20. M a n si, t. 9 , kol. 914.

445 Syn. turoneński (Tours) II z r. 567, kan. 19. M a n si, t. 9, kol. 797.

${ }_{446}$ Syn. turoneński (Tours) II z r. 567, kan. 19. Tamże.

447 Por. np. Syn. paryski $V z r .615$, kan. 8. M a n s i, t. 10, kol. 541; syn. emeryteński r. 666 , kan 18 . M a n si, t. 11, kol. 85.; pot. także Syn agateński $z$ r. 506, kan. 22 (przyt. w odn. 564).

448 Por. Syn. aureliański $I z r .311$, kan. 15. Man si, t. 8, kol. 354.

449 Por. Syn. kabiloński (conc. Cabilonense) $z r$. okoto 650, kan. 11.

Mans i, t. 10, kol. 1191.

450 Por. Syn. epaonenski (conc. Epaonense) z r. 517, kan. 7. M a n s i, t.8, kol. 560, oraz Syn. agateński z r. 506, kan. 22. Tamże, kol. 328.

451 Por. Syn. agateński $z$ r. 506, kan. 54. Tamże, kol. 334.; kanon powyższy ze zmianą tylko przypadku jednego wyrazu powtórzył syn. epaoneński (conc. Epaonense) z r. 517, kan. 8, Tamże, kol. 560.

${ }_{452}$ Por. Syn. emerytański $z r .666$, kan. 18, przy.t. w odn. 447. 
7. W stosunku do zwykłych wiernych archiprezbiterzy korzystaja z władzy napominania i karcenia do tego stopnia, że, gdyby kto $\mathrm{z}$ parafian w sposób uporny odnosił się do ich zarządzeń, mają obowiązek wzbronić mu dostępu do kościoła, a nawet, jak nakazywało prawo państwowe, obłożyć go odpowiednią grzywną ${ }^{453}$. W szczególności powinni czuwać, by zgodnie z zarządzeniem władz cywilnych, nikt w dni świąteczne nie spełnial prac służebnych i nie żył w związkach kazirodczych, o winnych zaś, o ile okazaliby się niepoprawnymi, donosić biskupowi, lub sędziemu świeckiemu ${ }^{4 \check{5}}$.

8. Na koniec, mieli obowiązek co rok w miesiącu maju brać udział $w$ synodzie diecezjalnym ${ }^{45 \tilde{5}}$.

Niektóre czynności były wyjęte spod władzy archiprezbiterów i zastrzeżone biskupowi, a mianowicie:

1. uroczyste udzielanie w świątyni błogosławieństwa ${ }^{456}$.

2. jednanie z Kościołem publicznych grzeszników ${ }^{4 \check{r}}$

3. udzielanie sakramentu bierzmowania, z wyjątkiem wypadku, gdy porzucający herezję jest ciężko chory i nie może zwlekać $\mathrm{z}$ przyjęciem tego sakramentu ${ }^{458}$.

${ }^{453}$ Syn. autisjodoreński, z r. 578, kan. 44. IVI a n s i, t. 9, kol. 916.

454 K u rts cheid B., dz. c, t. 1, s. 169, gdzie autor za Lo en in g'e $m$ E., Geschichte des deutschen Kirchenrechts, Strassburg 1878, t. 2, s. 457, cytuje edykt Gunterhrama z 10 listopada 585 r. i Childeberta Ir z 29 lutego $596 \mathrm{r}$.

${ }^{455}$ Syn. autisjodoreński $z$ r. 578, kan. 7. M a n s i, t. 9, kol. 913.

456 Syn. agateński $z$ r. 506 (K urts cheid B., dz. c., t. 1, s. 169, mówi tu o Syn. agateńskim z r. 529), kan. 44. M a n si, t. 8, kol. 332.

457 Przepis ten odnosił się np. do odpadłych od wiary i później do niej wracających, jak o tym świadczy syn. aureliański IV z r. 541, kan. 8. M a n si, t. 9, kol, 114. Rớwnież prawem tym byli objęci winni rozmyślnego zabójstwa, o ile dobrowolnie oddawali się $\mathrm{w}$ ręce władz i szczerze za swój występek żałowali.

Jednania $z$ Kościołem publicznych grzeszników biskup dokonywał zwykle za pośrednictwem archiprezbitera, lub późniejszego jego następcy, dziekana, jak to wynika $z$ Capitula anno XII episcopatus superaddita arcyb.. z Reims Hinkmara (um. 882), c. 1.. M i g n e, P. 2., t. 125, kol. 793 .

${ }_{458}$ Syn. epanoeński $z$ r. 517, kan. 16. M a n si, t. 8, kol. 561. 
4. święcenie olejów św. ${ }^{459}$.

5. błogosławienie wdów i panien Bogu się poświęcających ${ }^{460}$.

6. wydawanie tzw listów pokoju, które by miały wartość w całym Kościele ${ }^{461}$.

7. władza dyscyplinarna nad klerem i w sprawach religijno-moralnych nad świeckimi; ustanawianie duchownych przy kościołach i kaplicach oraz wydawanie zezwoleń na wznoszenie budynków dla celów kultu ${ }^{462}$.

8. ostateczna decyzja $\mathrm{w}$ wielu sprawach związanych $\mathrm{z}$ administracją majątku parafialnego ${ }^{463}$.

Po bliższym rozpatrzeniu się $w$ powyższych zarządzeniach dochodzimy do wniosku ${ }^{464}$, że mówią one o archiprezbiterach raczej jako o duszpasterzach i proboszczach, niż o właściwych przełożonych, wyposażonych w zwykłą władzę rozkazodawczą i karną. Wprawdzie niektóre kanony upoważniają ich do karania tak niższych duchownych, jak i świeckich ${ }^{465}$, ale bezsprzecznie są one w całokształcie prawodawstwa współczesnego zjawiskiem odosobnionym i zasadniczo nie zawierają nic takiego, co by się nie mieściło $w$ pojęciu przeciętnej władzy ojcowskiej. Bo, ostatecznie, tylko taka archiprezbiterom w owym czasie przysługuje; oni jedyrie czuwaja nad ludem i duchownymi ze swojej parafii i najwyżej donoszą biskupowi o zauważonych przez sieblie wykroczeniach, a ten je dopiero w odpowiedni sposób karze.

458 Syn. toletański I $z$ r. 400, kan. 20. M a n si, t. 3, kol. 1002, oraz Syn. wazeriski II z r. 442, kan. 3, Tamże, t. 6, kol. 453.

460 Zob. odn. 74.

*61 Por. np. Syn antiocheŕski. $I z r .341$, kan. 8. M a n si, t. 2, kol. 1323.

${ }_{462}$ Zob. Syn. arauzykański $z$ r. 441, kan.. 10. MI a n si, t. 6, kol. 437-438. Zob. także odn. 453.

463 Por. zwlaszcza Syn. agateński z r. 506, kan. 22 (przyt. w odn. 450).

${ }_{464}$ Zob. o tym A m a ni u u A., Archiprètre, j. w., kol. 1008-1009.

465 Do tych postanowień należą: syn. $z$ Tours II $z$ r. 567, kan. 19 (przyt. w odn. 560), oraz syn. z Auxerre z r. 578, kan. 44 (przyt. w odn. 567) - A m a nieu A., Archiprètre, j. W., kol. 1008, ostatni ten synod umieszcza w r. 580. 
W stosunku do innych kapłanów, stojących na czele parafii i nie posiadających zresztą tytułu archiprezbitera, nawet i takiej władzy nie przejawiają. Parafie w owym czasie są na ogół nieliczne i prowadzą życie prawnie odosobnione, samodzielne zawisłe zasadniczo od ordynariusza i jego archidiakona.

\section{b. Rozwój uprawnień}

Archiprebziter, jako przełożony pewnego okręgu obejmującego kilka parafii i wkrótce zwany dziekanem, to dzieło następnego okresu, noszącego w historii nazwę epoki Karolingów. Zjawił się on na terenie Francji, gdzie w tym czasie powstają liczne kościoły parafialne, co zmusiło władze duchowne do stworzenia nad nimi czynnika kontrolnego, bardziej niż dotychczasowy udoskonalonego.

We Włoszech bowiem i w Niemczech w omawianym okresie stan rzeczy pozostaje niezmieniony.

$\mathrm{Na}$ półwyspie Apenińskim ${ }^{466}$ obok stolic biskupich, erygowanych wkrótce po edykcie mediolańskim i dość długo vrystarczających na potrzeby religijne wiernych, z czasem powstają świątynie również po wsiach, posiadających pełne prawa kościołów parafialnych. Noszą one nazwę „plebes”, lub „ecclesiae plebanae”, ksiądz zaś przy nich zamieszkały - ,plebanus". Gdy liczba duchowieństwa parafialnego $z$ biegiem lat się zwiększy, ten ostatni otrzyma tytuł archiprezbitera wraz z wszystkimi znanymi nam, a więc niewielkimi uprawnieniami, czego dowodem odbyty $w$ połowie IX $w$. synod $w$ Pawii ${ }^{467}$.

${ }^{466} \mathrm{Kurtsch}$ id B., dz. c., t. 1, s. 263-264.

${ }_{467}$ Peltier, dz. c., t. 2, s. 377, robi uwagę: „Ce concile (sc. Papiense seu Ticinense) fut tenu sur la fin de l'an 850. Baronius dit qu'il y avait à Ivrée, en 844 et 845 "... I I a n s i, t. 14, kol. 930, nadaje temu synodowi nazwę, ,synodus Regiaticina a. 850". Ku rtscheid B., dz. c., t. 1, s. 263, nazywa go "Papiense” i przezornie umieszcza między $r$. 845-850. Zagadnienie władzy archiprezbitera poruszone zostało $w$ następujących kanonach tego synodu:

kan. 6; M a n si, t. 14, kol. 931 . 
Był wybierany przez miejscowe duchowieństwo i parafian, lecz ostatecznie zatwierdzał go biskup ${ }^{468}$. Niektórzy autorzy nazywają go dziekanem, choć w rzeczywistości z tym urzędem niewiele miał wspólnego.

Podobne stosunki, jak w Italii, panowały współcześnie prawie $w$ całych Niemczech ${ }^{469}$ z tą różnicą, ze obszar parafii był niepomiernie wiẹszy i obok archiprezbiterów lokalnych w w. X i XI byli znani przejezdni, wysyłani przez biskupów w celach wizytacyjnych. Władza ich rozciągała się na pewne części diecezji zwane dziekaniami (decania) i w swej treści bardzo przypominała uprawnienia archidiakonów okregowych, których zresztą tytul w XII w. przejmują. Powoli jednak również i tutaj instytucija dziekanów zaczyna wchodzić $w$ użycie i w w. XII jest już powszechnie znana.

Właściwą kolebką dziekana wiejskiego jest państwo Franków. Dzięki sprzyjającym warunkom politycznym ${ }^{470}$ wysiłki misjonarzy lącznie z zabiegami Karola Wielkiego (r. 768-814) doprowadziły do niebywałego rozkwitu kościelnego życia ${ }^{47 i}$. By ułatwić spełnianie obowiązków religijnych nowym wiernym, zamieszkałym na głębokiej prowincji, zwłaszcza niewiastom, młodzieży i osobom słabym, dla których puszcze, roztopy i znaczna odległość od dotychczasowego kościoła stanowiły zbyt wielką przeszkodę do pokonania ${ }^{472}$, już od VII w. tak na terenie wielu istniejących parafii, jak i poza ich obrębem zaczęto wznosić nowe świątynie i w niedługim czasie, mimo

kan. 13. Tamże, kol. 935. Tekst ten prawie dosłownie powtarza ,capitulare 12 Lamberti imperatoris $z$ r. 898 . IM i g n e, P L., t. 138, kol. 814 , oraz c. $4, \mathrm{X}, \mathrm{I}, 24$.

${ }_{488}$ Por. Kurtscheid B., dz. c. t. 1, s. 263-264 (autor powołuje się na kan. 4 i 5 synodu z Pawii z r 850. zachodzi tu pewne nieporozumienie, gdyż wspomniane kanony ani słowa nie potrącają o omawiany tekst) oraz c. 20, D. 63.

${ }_{469}$ Por. Kurtscheid B., dz. c., t. 1, s. 264.

470 Zob. Szcześniak W., dz. c., t. 1, s. 236-238.

${ }_{471}$ Zob. Kurtscheid B., dz. c., t. 1, s. 262, oraz A manieu A., Archiprêtre, j. W., kol. 1009-1010.

${ }_{472}$ Syn. tuluzański (Caroli II synodus apud Tolosam) z r. 844, kan. 7. Migne, P. L., t. 138, kol. 534 . 
pewnych sprzeciwów ze strony niektórych synodów ${ }^{473}$ lub biskupów ${ }^{474}$, po uprzednim ścisłym wytyczeniu granic przyznawać im także uprawnienia parafialne, jak prawo udzielania chrztu, chowania zmarłych i pobierania dziesięcin.

Gdy liczba parafii osiągnęła dość znaczną wysokość, wyłoniła się potrzeba stworzenia nad nimi odpowiedniego organu kontrolnego, ponieważ dotychczasowa władza biskupa i archidiakona nie zdołała zaradzić potrzebom i utrzymać sprężysta administrację kościelną. Władzom centralnym diecezji nie mogli przyjść z pomocą chorepiskopi, gdyź ci tracili już na znaczeniu ${ }^{475}$, archidiakoni okręgowi jeszcze się nie upowszechnili ${ }^{476}$, zaś istniejący archiprezbiterzy wiejscy byli pozbawieni wszelkich skutecznych pełnomocnictw ${ }^{477}$.

Piętrzące się trudności Kościół rozwiązał przez powołanie do życia instytucji nowych archiprezbiterów, a właściwie dzie-kanów wiejskich. Według intencji prawodawcy mieli oni stać na czele pewnej, niezbyt wielkiej liczby parafii oraz stanowic czynnik kontrolny i pośredniczący między podległym sobie duchowieństwem a biskupem i jego archidiakonem, lub te $\dot{z}$ archidiakonem okręgowym, gdy ten wejdzie do zarządu diecezją, co we Francji stanie się zjawiskiem zwykłym już pod koniec IX w. ${ }^{478}$.

Wyraz „dziekania" (decenia) jest bodaj po raz pierwszy wymieniony $\mathrm{w}$ postanowieniach synodu $\mathrm{z} \mathrm{r}$. 844, odbytego $\mathrm{w} \mathrm{Tu}-$ luzie $\mathrm{w}$ związku $\mathrm{z}$ zarządzeniami, jakie powziął Karol Łysy

${ }^{473}$ Por. np. syn. meldeński (de Meaux) z r. 845, kan. 48. IM a n s i, t. 14 , kol. 830 .

474 Por. np. Rodulfi capitula, biskupa z Bourges z r. 857, kan. 20. M ig n e, P. L., t. 119, kol. 713.

475 Por. odn. 78 nn., a zwlaszcza odn. 87.

476 Por. tekst do odn. $145-250$.

477 Por. odn. 464.

478 Por. Kurtscheid B., dz. c., t. 1, s. 262, oraz odn. 147. Z tak pojętym początkiem dziekanatu, odgórnym niejako, nie trudno będzie pogodzić to, co wyżej powiedziano w tekście do odn. 18-19, gdzie przedstawiono oddolne jego zaczątki. Oba kierunki, zmierzające do właściwego urządzenia stosunków kościelnych, podały sobie ręce, by stworzyć instytucję dziekanatu wiejskiego. 
w celu sprawnego zebrania dziesięcin należnych biskupom od parafii ${ }^{479}$.

Należy mniemać, że nowa instytucja dziekanii i dziekanów sięga przynajmniej początku IX w. i jest współczesna, a nawet niekiedy wcześniejsza od urzędu archidiakonów okręgowych ${ }^{480}$, o dziekanach bowiem najprawdopodobniej mówi synod paryski VI z r. 829, kiedy wspomina ogólnie o urządnikach biskupich (episcoporum ministri), sprawujących w swoich okręgach władzę nad duchownymi i świeckimi ${ }^{481}$, do których to urzędników synod z Aix- la -Chapelle odprawiony w r. 836 wyraźnie zalicza archiprezbiterów ${ }^{482}$.

Właśnie ostatnia sprawa, mianowicie stosunek pojawiających się dziekanów do dotychczasowych, choć zmienionych archiprezbiterów wiejskich nastręcza pewne trudności ${ }^{483}$. Na pierwszy rzut oka, przy pobieżnym przejrzeniu najstarszych pod-stawowych dokumentów prawnych ${ }^{484}$ zdawałoby się, że dziekan i archiprezbiter wiejski to dwa pojęcia całkowicie się pokrywające. W rzeczywistości są to postacie w pewnym, przynajmniej formalnym znaczeniu różne. By odpowiedzieć w sposób należyty wymogom chwili, dla rozciągnięcia potrzebnej opieki nad powstającymi ośrodkami religijnego kultu i zwiększającą się liczbą parafian oraz zamieszkującym przy kościołach i kaplicach duchowieństwem, na wzór urządzeń wypróbowanych $\mathrm{w}$ klasztorach biskupi stwarzają niejako nowy urząd, którym zazwyczaj obdarzają dotychczasowych archiprezbiterów wiejskich. Ci najbardziej nadawali się do podźwigniecia

479 Caroli II synodus apud Tolosam a. 844, c. 3. M i g n e, P. L., t. 138, kol. 532. Por. także Aichner S., dz. c., s. 433 i tamże odn. 2, oraz Am an i e A., Archiprêtre, j. w., kol. 1010.

${ }^{480} \mathrm{Kurtsch}$ eid B., dz. c., t. 1, s. 262, i A m a ni eu A., tamże. 481 Kan. 25 tego synodu. Mansi, t. 14, kol. 555.

482 Rozdz. 2, $\S 2$, kan. 4 tego synodu. H efele-L e cle r c q, dz. c., t. 4 , cz. 1 , s. 95 .

483 Zob. o tym Amanieu A., Archiprêtre, j. W', kol, 1010.

484 Por. np. Syn. tolozański $z$ r. 844, c. 3 (przyt. w odn. 593); syn. z Aix-la-Chapelle z r. 836, rozdz. 2, $\S 2$, kan. 4 (przyt. w odn. 596); oraz Epist. 52 Hinkmara, arcybiskupa z Reims (um. 882). MI i g n e, P. L., t. 126, kol. 273. Zob. także Kurtscheid B., dz. c., t. 1, s. 262. 
wszystkich nowych i zarazem starych obowiązków, bo o tym świadczyła i dotychczasowa praktyka życia, wymagająca od nich ustawicznej czujności nad duchowieństwem oraz wiernymi, i przy tym mieszkali w ośrodkach najbardziej dogodnych do sprawowania potrzebnej kontroli ${ }^{485}$.

$\mathrm{Z}$ tej też przyczyny noszą oni przez jakiś czas w niektórych wypadkach tytuł archiprezbiterów, w innych - dziekanów, lub też jedną i drugą nazwę jednocześnie. Wkrótce oba te terminy ulegają całkowitemu zidentyfikowaniu ${ }^{486}$.

Podobne zjawisko zachodzi z tytułem okręgów, nad którymi nowi urzędnicy zaczęli sprawować władzę. Nosiły one często tradycyjną nazwę ,archiprezbyteratus”, niekiedy „,christianitas" ${ }^{487}$, lub wprost „decania" ${ }^{488}$. Upowszechniły się niezwykle szybko. Diecezje francuskie już pod koniec $\mathrm{X}$ w. były na nie podzielone ${ }^{489}$. Według Dekretałów miało to być zasadą w całym Kościele ${ }^{490}$.

Oczywiście nowi archiprezbiterzy czyli dziekani zachowują uprawnienia archiprezbiterów dotychczasowych i zarazem wybitnie je wzmacniają ${ }^{491}$. Zakres ich władzy będzie stale wzrastał do w. XIII ${ }^{492}$

1. Przede wszystkim przysługiwać im będzie prawo wizytacji. Sprawę tę szeroko omówił w swoich zarządzeniach Hinkmar,

485 A manieu A., Archiprêtre, j. W., kol. 1010. Por. także Ku r ts ch eid B., dz. c., t. 1, s. 261-262, oraz odn. 132.

480 Por. Kurtscheid B., dz. c., t. 1, s. 262, oraz Amanieu A., Archiprêtre, j. w., kol. 1010-1011 i 1013. Już za czasów Innocentego III (r. 1198-1215), od którego pochodzi c. 7, § 2, X, de officio archidiaconi, I, 23, mówiono: „Archipresbyteri, qui a pluribus decani nuncupantur".

487 Syn. Koloński $z$ r. 1280, wstęp. M a n s i, t. 24, kol. 344.

488 Por. choćby kan. 3 synodu odbytego w r. 844 w Tuluzie (przyt. w ođn. 479).

489 A m a nieu A., Archiprêtre, j. w., kol. 1011.

499 C. 4, X, de officio archipresbyteri, I, 24 (tekst ten pochodzi, jak widać $z$ nadpisu, $z$ uchwał synodu odbytego $w$ Rawennie w r.. 868).

491 Zob. A m a nieu A., Archiprêtre, j. w., kol. 1011 nn.

492 Zob. niżej, gdzie o ograniczeniach władzy dziekańskiej. 
arcybiskup z Reims (zm. $882^{493}$ ). W myśl jego poleceń dziekan ma co rok osobiście odbywać wizytacje podległych sobie kościołów i kaplic oraz pracującego przy nim duchowieństwa i z jej wyniku zdawać ścisłe sprawozdanie swemu biskupowi ${ }^{494}$. W czasie wizytacji zbada:

A. Czy duchowni posiadają święcenia kapłańskie i kanoniczną instytucję przy kościele lub kaplicy, przy której pracują ${ }^{495}$.

B. Jaka jest rozciągłość parafii i czy jej uposażenie odpowiada przepisom prawa kościelnego ${ }^{496}$.

C. Wielu parafia liczy mieszkańców, którzy przecież przez uiszczanie dziesięciny mają zapewnić miejscowemu duchowieństwu dostateczne utrzymanie ${ }^{497}$.

D. czy przybory ołtarzowe są zrobione $z$ odpowiedniego materiału i znajdują się $w$ należytym stanie oraz czy relikwie są nienaruszone i szczelnie zamknięte ${ }^{408}$.

E. czy znajdują się w odpowiedniej liczbie i są przechowywane w należytym porządku księgi liturgiczne ${ }^{499}$.

F. czy bielizna i paramenty kościelne są czyste i chronione przed niszczeniem ${ }^{500}$, czy kościół posiada dostateczną ilość świec ${ }^{501}$ oraz naczynia do olejów św. i wiatyku, jak również czy kielich $\mathrm{z}$ pateną został sporządzony ze szlachetnego kruszczu ${ }^{502}$.

G. czy jest piscyna przy kościele ${ }^{503}$, w jakim stanie znaj-

493 Capitula quibus de rebus magistri et decani per singulas ecclesias inquirere, et episcopo renuntiare debeant. Migne, P. L., t. 125, kol. $777-786$.

494 Tamże, kol. 777.

495 Kan. 1. Tamże.

496 Kan. 2. Tamże.

497 Kan. 3. Tamże.

498 Kan. 4. Tamże, kol. 778.

${ }_{499}$ Kan. 5. Tamże.

500 Kan. 6. Tamże.

501 Kan. 12. Tamże, kol. 779.

502 Kan. 8 i 9. Tamże.

503 Kan. 7. Tamże. 
duje się dach świątyni i drzwi kościelne ${ }^{504}$, czy mieszkanie księdza jest położone w sąsiedztwie kościoła i czy w pobliżu nie ma domów o podejrzanej opinii ${ }^{505}$ oraz czy kościół parafialny posiada i z jakiego materiału dzwony ${ }^{506}$.

H. jak kapłan pracujący w parafii spełnia swoje obowiązki duszpasterskie, czy w szczególności osobiście, a nie za pośrednictwem świeckich, odwiedza chorych parafian i $w$ razie potrzeby udziela im ostatnich sakramentów, pozostalym zaś wiernym komunii św. ${ }^{507}$, czy oleje św. przechowuje $z$ należytym szacunkiem ${ }^{508}$ i czy sam, lub w jego zastepstwie diakon, albo subdiakon pierze korporały i puryfikaterze ${ }^{509}$.

I. czy dochody powstałe $\mathrm{z}$ dziesięcin zgodnie $\mathrm{z}$ prawem kanonicznem są dzielone uczciwie na 4 części $i$ to pod czujnym okiem dwu, lub trzech nieposzlakowanych parafian, jak również czy część należna biskupowi i miejscowemu kościołowi nie doznaje jakiego uszczerbku, o czym ordynariusz winien być corocznie powiadamiany ${ }^{510}$, czy wreszcie zamiast chorych i biednych $\mathrm{z}$ należnej im części nie korzysta najbliższa rodzina księdza, oczywiście z wyjątkiem naprawdę biednych niektórych krewnych ${ }^{\tilde{1} 11}$.

J. czy kapłan, który nie posiada własnej ojcowizny, nie bogaci się $w$ sposób niezgodny $z$ prawem i z krzywdą dla kościoła, lub, co gorsza, czy tych dochodów nie obraca na życie gorszące i występne ${ }^{512}$, przeciwnie, czy stara się utrzymać przy kościele szkółkę, w której odpowied-

504 Kan. 13 i 15. Tamże.

505 Zob. kan. 15, przyt. W poprzednim odn.

506 Kan. 10. Tamże.

s07 Kan. 10. Tamże.

508 Kan. 9 (przyt. W odn. 502).

sog Kan. 7 (przyt. w odn. 617).

s10 Kan. 16. Tamże.

s11 Kan. 17. Tamże.

s12 Kan. 18. Tamże. 
nio uposażony duchowny uczyłby dzieci najprostszych przedmiotów, nie wyłączając śpiewu i ceremonii kościelnych ${ }^{513}$.

K. na koniec - czy kapłan nie mieszka razem z niewiastami, jakim według kanonów nie wolno stale przebywać pod dachem plebanii; czy też do nich nie chodzi, lub one go odwiedzają ${ }^{514}$, czy nie uczęszcza on do karczmy, albo nie goni za biesiadami, gdzie tak łatwo o swawolę ${ }^{515}$.

Rzecz zrozumiała, wykraczających powinien dziekan wszelkimi sposobami starać się naprawić ${ }^{516}$. Gdyby jego starania nie odniosły pożądanego skutku, kapłan niepoprawny ma być pozbawiony stanowiska i zdegradowany ${ }^{\mathbf{5 1 7}}$. Oczywiście w sprawie tak poważnej nie wolno postępować zbyt pochopnie. By kapłana postawić w stan oskarżenia i dowieść mu winy, za którą ma ponieść surową karę, nie wystarczy, jak w innych wypadkach, świadectwo dwu, czy trzech świadków. Trzeba, by występku mu dowiodło siedmiu, niekiedy 14-tu, a w wyjątkowych okolicznościach nawet 21 poważnych i roztropnych świadków ${ }^{518}$. Gdy jedynie ogólnie usłyszano niepochlebną opinię o księdzu, dla oczyszczenia się z zarzutów dosyć będzie, jeśli ten im zaprzeczny i oświadczenie swoje potwierdzi przysięgą ${ }^{519}$. Dodać należy, że wizytacja dziekańska, choć dawała

513 Kan. 11. Tamże.

514 Kan. 21. Tamże, kol. 780.

515 Kan. 20. Tamże, kol. 779.

516 Kan. 26. Tamże, kol. 785-792.

517 Kan. 21. Tamże, kol. 783. Por. także konstytucje Ryszarda (Ricardi), biskupa. Sarum, z r. 1217, kan. 7. MI a n s i, t. 22, kol. 1108. Biskup ten zagroził dziekanom, że oni sami będą tak surowo karani, jeśli zaniechają karać w sposób wlaściwy duchowieństwa sobie podwładnego. Zarządzenie to przypomnial jego następca, biskup Walter de Kirkham, w r. 1225, rozciągając ustanowioną przez swego poprzednika karę na wszystkich proboszczów, którzy zaniedbaliby powiadomić dziekana o uchybieniach moralnych parafialnego duchowieństwa. Zob. o tym Mansi, t. 23, kol. 898.

518 Kan. 22. IM i g n e. P. L., t. 125, kol. 784.

519 Kan. 24. Tamże, kol. 785. 
prawo do pewnego wynagrodzenia ${ }^{520}$, winna nosić charakter sizromny i nie obciążać wizytowanych ${ }^{521}$.

2. Oprócz corocznego wizytowania parafii posiada dziekan obowiązek zwoływania co miesiąc zebrań podległego sobie duchowieństwa. Biskup Rikulf (zm. $902^{522}$ ) pod koniec IX w. poleca, by na tych zjazdach zastanawiano się, jak najlepiej spełnić swoje obowiązki, omawiano szczególniejsze wypadki, które zwykły się wydarzać w codziennym życiu parafialnym, i w jaki sposób duszpasterz winien wówcz̧as się zachować. Obrady mają być połączone $z$ modlitwą $w$ intencji panującego, zmarłych konfratrów i osób najbliższych. Podczas ich trwania należy unikać objadania się i opilstwa ${ }^{523}$, a po wyczerpaniu porządku dziennego i spożyciu skromnego posiłku wyjechać do swojej parafii ${ }^{524}$.

W dobie rozkwitu instytucji dziekanatu na zebraniach tych odczytywano statuty ostaniego synodu diecezjalnego przy czym dziekani mieli zważać, by je zachowywano na równi z wszelkimi zarządzeniami ordynariusza i archidiakona, nieposłusznych zaś odpowiednio karali ${ }^{525}$.

Podkreślić wypada, że do uczestnictwa w obradach byli

520 Synod. klaromonteński (Claromontensis) $z \quad r .1268$, kan. 8. M a n s i, t. 23 , kol. 1211.

${ }^{521}$ Sob lateraneński III $z$ r. 1179, kan. 4. Ma ns i, t. 22, kol. 220. Powyższe zarządzenie soborowe $\mathrm{w}^{i}$ głównej swej treści zostało powtórzone np. w kan. 5 synodu londyńskiego $z$ r. 1200 (M a n si, t. 22, kol. $715-716)$.

ธ22 Zob. notatkę historyczną u Mign e’a, P. L., t. 131, kol. 16 .

523 Kan. 20 statutów biskupa Rikulfa. Mign e, P. L., t. 131, kol. 22-23. Por. także konstytucję biskupa Waltera de Kirkham z r. 1255. IM a nsi, t. 22, kol. 898-899. Są one dalekim echem zarządzeń arcybiskupa z Reims Hinkmara (um. 882), jak o tym świadczą jego Capitula anno XII episcopatus superaddita, c. 1, Migne, P. L., t. 125, kol. 793.

524 H in cmar, Capitula presbyteris data, kan. 15. Migne, P. L., t. $125, \mathrm{kol}$. 777 .

525 Syn. moguncki (de Mayence) $z$ r. 1225, kan. 14. Pelti er, dz. c., t. 1, kol: 1241; Syn. trewirski $z$ r. 1227 kan. 8. NI a n s i, t. 23, kol. 31, oraz Syn. koloński $z$ r. 1280, kan. 16, M a n i, t. 24, kol. 360 . 
obowiązani kondekanalni proboszczowie, wikariusze oraz kapelani ${ }^{526}$.

3. Zarazem dziekan natychmiast powiadamia władzę diecezjalną o wszystkim, co może ją interesować z życia podległego mu okręgu ${ }^{527}$. A więc donosi o wypadkach śmierci wśród duchowieństwa ${ }^{528}$, informuje, którego kapłana chciałby widzieć kolator na opróżnionym stanowisku ${ }^{529}$, wreszcie śpieszy z wiadomością o takich smutnych wydarzeniach, jak zbyt jaskrawe niestosowne zadawanie sie duchownych z kobietami, uczęszczanie księży do karczem, uprawianie przez nich lichwy i handlu, lub téz błogosławienie tajnych związków małżeńskich ${ }^{530}$.

4. On również z podległym sobie duchowieństwem świeckim i zakonnym osobiście, lub naskutek rozumnej przeszkody przez upoważnionego zastępcę bierze udzial w odprawianym corocznie synodzie diecezjalnym. Na nim występuje $w$ albie i stule i zajmuje honorowe miejsce przed zwykłymi duchownymi ${ }^{531}$.

5. Powinien posiadać specjalną pieczęć urzędową i znaczyćc nią wszelkie podpisywane przez siebie akta ${ }^{532}$.

6. Więcej, w okresie szczytowego rozwoju swoich uprawnień dochodzi on nawet do posiadania prawdziwej władzy sądowniczej. Przysługuje mu ona tak w stosunku do osób świeckich, jak i duchownych ${ }^{533}$, lecz na ogół

${ }_{526}$ Por. konstytucje biskupa Waltera de Kirkham z r. 1255 (przyt. w odn. 523).

${ }^{527} W$ tym czasie, tzn. W okresie rozkwitu instytucji dziekanatu, władzą przełożoną dla dziekanów są okręgowi archidiakoni i biskup. Por. o tym odn. 170.

528 Konstytucje synodalne biskupa paryskiego Odona (wg Mansi, t. 22, kol. 686, umarł w r. 1175, lub 1196), kan. 8. Mansi, t. 22, kol. 684. ${ }_{529}$ Syn. Chatesu - Gontier z r. 1231, kan. 3. M a n s i, t. 23, kol. 224.

530 Syn. trewirski $z$ r. 1227, kan. 8. M a n i, t. 23, kol. 31, oraz tamże, kol. 32.

531 Syn. koloński z r. 1280, wstęp. M a n s i, t. 24, kol. 344.

532 Zob. odn. poprzedni, jak również syn. odbyty w r. $1280 \mathrm{w}$ Poitiers (syn. Pictavensis), kan. 2. M a n si, t. 24, kol. 382.

533 Syn. odbyty $w$ Rouen w r. 1231, kan. 26. H ef ele-L e cle rq q, dz. c., t. 5, cz. 2, s. 1526 . 
w sprawach mniejszej wagi, jak np. kłótnie czy obelgi. Oczywiście od jego orzeczeń można apelować do Trybunału biskupiego ${ }^{534}$.

Ponieważ sądownictwo $\mathrm{w}$ odniesieniu do duchowieństwa zostało całkowicie wyjęte spod kompetencji czynników świeckich, w wypadku popełnienia jakiego przestępstwa przez kapłana $\mathrm{i}$ aresztowania go przez władze cywilne on na równi z archidiakonem powiadomi o wszystkim ordynariusza i dopilnuje, by duchownego uwolniono i $w$ celu rozpatrzenia sprawy oddano w ręce władzy kościelnej, która dla obrony swego przywileju sądowego $\mathrm{w}$ razie potrzeby nie cofnie się przed rzuceniem ekskomuniki ${ }^{535}$, lub interdyktu ${ }^{536}$.

$\mathrm{Na}$ mocy swej władzy sędziowskiej posiada on możność nakładania na winnych różnych grzywien. Od nich byli wolni ci, którzy w czasie procesu zdążyli sprawę załatwić między sobą $\mathrm{W}$ sposób polubowny ${ }^{53 \tau}$.

Co więcej, w niektórych wypadkach może stosować karę suspensy i ekskomuniki, oczywiście po wyczerpaniu wszelkich środków, jakie mu roztropność podyktować winna i przy zachowaniu koniecznych formalności prawnych ${ }^{538}$.

Natomiast spod jego kompetencji zostały wylączone sprawy o większym znaczeniu, jak: małżeńskie, tyczące się lichwy, czarów, umów testamentów, świętokupstwa i kryminalne oraz takie, za które duchownym grozi utrata beneficjum kościelnego, godności lub, co gorsza, degradacja. Jest to całkowicie zrozumiałe, gdyż, aby móc wyrokować w tego rodzaju zagadnieniach, trzeba posiadać odpowiednią wiedzę prawniczą i właści-

${ }^{534}$ Syn. odprawiony w Kompostelli w r. 1114, kan. 13. M a n s i, t. 21, kol. 121. (Nawiasowo dodaję, że, jak to wyjaśnia Hefele-Leclercq, t. 5, cz. 1, s. 547, w powyższym tekście nie należy upatrywać władz papieskich, lecz jedynie urzędy biskupie przy katedrze św. Jakuba w Kompostelli). Por. także S chmalzgrueber F., dz. c., t. 2, s. 141.

${ }_{535}$ Syn. W Rouen z r. 1231 (conc. Rotomagense), kan. 8. M a n s i, t. 23, kol. 217.

536 Por. A m anieu A., Archiprêtre, j. w., kol. 1014.

537 Syn. odbyty w Rouen z r. 1231, kan. 25. Mansi, t. 23, kol. 216-217.

538 Syn. "apud pontem audemari" $z r .1279$, kan. 16. M a ns i, t. 24, kol. 224. 
wy autorytet. Dziekan jedynie wówczas może wyrokować w sprawach małżeńskich, gdy został do tego upoważniony przez swego biskupa, albo niekiedy przez Stolicę Apostolską ${ }^{539}$.

\section{c. Ograniczenie władzy}

Jak każda instytucja, również dziekani, nie poddani należytej kontroli, zaczęli się dopuszczać różnych nadużyć ${ }^{540}$. Idąc w ślady archidiakonów, u̇stanawiali sobie często oficjałów, wikariuszów generalnych i najrozmaitszych urzędników, którzy $w$ ich imieniu sprawowali sądy $w$ wielu miejscach dekanatu ${ }^{541}$. Synody XIII-wieczne, przypominając dawne przepisy o dziekanach i robiąc jedynie wyjątek dla archidiakona katedralnego, tak dziekanom, jak i archidiakonom wspomnianej praktyki surowo zabroniły pod karą nieważności ogłaszanych wyroków ${ }^{542}$.

Do bardzo niemiłych trzeba zaliczyć nadużycia na tle materialnym. Oto niektórzy dziekani powodowani chęcią zysku nie dopuszczali, by strony spór wiodące dobrowolnie między sobą się godziły, gdyź wtedy oni sami tracili tytuł do wyna-

530 Por. Syn. „apud Castrum Gonteri门” z r. 1251, kan. 2. Mansi, t. 23, kol. 224.; syn. "apud Vallem Guidonis" (de Laval) z r. 1241, kan. 4. Mansi, t. 23, kol. 351-552.; kan. 13 synodu adbytego $w$ Reims w r. 1231. Hefel-Leclercq, dz. c., t. 5, cz. 2, kol. 1525.; syn. oksfordzki (conc. Oxoniense) z r. 1222, kan. 19. Mansi, t. 22, kol. 1157-1158.; syn. odprawiony $w$ Rouen $\mathrm{z}$ r. 1231, kan. 13, IM a n si, t. 23, kol. 215.; oraz syn. odbyty w r. $1280 \mathrm{w}$ Poitiers (syn. Pictavensis) kan. 2. M a n s , t. 24 , kol. $381-382$.

549 Por. $z$ poprzedniego odn. szczególnie kan. 4 synodu ,apud Vallem Guidonis" (de Laval) z r. 1241.

541 Por, odn. 173, 175 i 188.

542 Syn. „apud Castrum Gonterii” z r. 1231, kan. 12. Mansi, t. 23, kol. 236.; jak również syn. "apud Vallem Guidonis" (de Laval) z r. 1241, kan. 4. Tamże, kol. 552. Por. także Syn. $z$ Poitiers z r. 1280, kan. 2 (przyt. $\mathrm{w}$ odn. 531.; Syn. langezjeński (conc. Langesiense) $z r .1278$, kan. 2 (Mansi, t. 24, kol. 212).; Syn. $z$ Tours $z$ r. 1239, kan. 8 (tamże, t. 23, kol. 499); oraz Syn. Situryceński (conc. Situricense) z r. 1286, kan. 4 (tamże t. 24, kol. 627). 
grodzenia ${ }^{\text {43 }}$. Inni z podobnych względów umyślnie opóźniali wydawanie wyroków, lub, odwrotnie, przyśpieszali je, albo też kierowali się stronniczością przy rozsądzaniu spraw, za co przecież groziła kara klątwy ${ }^{544}$. Stronniczość ta przybierała niekiedy formy wprost krzyczące, bo albo zbyt późno przesyłano wezwanie oskarżonemu, albo w ogóle o toczącym się pro-cesie go nie powiadamiano $w$ tym celu, by mu utrudnić lub wręcz uniemożliwić obronę. A przecież stan prawny był pod tym względem aż nadto jasny ${ }^{545}$. Dziekani wiedzieli, że nie tylko na prośbę stron, ale z poczucia obowiązku zawsze winni być gotowi do obrony pokrzywdzonych tak świeckich, jak zwłaszcza duchownych i to bez oglądania się na jakiekolwiek korzyści materialne ${ }^{546}$.

Do mniej przykrych nadużyć zaliczyć należy, jeśli dziekani $z$ okazji odprawiania przez siebie wizytacji parafialnych domagali się umyślnych wynagrodzeń, wzbronionych im przez so-bór powszechny lateraneński III w r. $1179^{547}$. Znajdowali sie jednak wśród nich tacy, którzy chętnie przyjmowali datki, lub wprost je wymuszali, by patrzeé przez palce na wykroczenia podległego sobie duchowieństwa, za co przecież groziła utrata stanowiska ${ }^{548}$.

Inni wreszcie, choć to było zabronione pod groźbą restytucji, pod pozorem ścigania przestępstw nakładali kary pieniężne, z których dochód sobie przywłaszczali ${ }^{549}$.

Za powyższy stan rzeczy byli odpowiedzialni w dużym stopniu niektórzy biskupi, zbyt zajęci sprawami politycznymi ${ }^{5} \mathfrak{s}$

543 Zob. odn. 169.

544.4 Konstytucje Ryszarda (Ricardi) Poore, biskupa Sarum, ogłoszone ok. r. 1217, kan. 51 IM a n s i, t. 22, kol. 1123.

545 Syn. lambeteński (conc. Lambethense) z r. 1281, kan. 12. Mansi, t. 24, kol. 413 .

546 Konstytucje synodalne pewnego biskupa angielskiego (Episcopi Anonymi), ogloszone ok, r. 1237. IM a n si, t. 23, kol. 475.

547 Zob. odn. 521.

548 Syn. londyński $z$ r. 1108, kan. 8, M a n si, t. 20, kol. 1230.

${ }_{549}$ Syn. salmurieński (conc. Salmuriense) $z r$. 1294, kan. 3. IM a n si, t. 24, kol. 1123-1124.

550 Por. odn. 142. 
i względy materialne przenoszący nad obowiązki swego wysokiego urzędu. Przecież nie do wyjątków należało, jeśli ordynariusz, który z zainteresowanym archidiakonem decydował, kto miał zostać dziekanem lub tej godności pozbawionym ${ }^{551}$, stanowisko dziekańskie odstępował więcej dającemu i to niekiedy $z$ władzą nad paroma dekanatami ${ }^{552}$, albo też dziekanami mianował ludzi świeckich, zbyt młodych, bez oglądania siẹ na ich przymioty moralne i, jeśli tak rzecz można, zawodowe ${ }^{553}$.

Zbyt często popełniane nadużycia musiały wywołać reakcję właściwych czynników kościelnych. Oto już Urban II na synodzie w Alwernii w r. 1095554 w sposób stanowczy przypomniał, że dziekanami mogą być jedynie kapłani ${ }^{555}$. Przepis ten został wcielony przez Gracjana do jego Zbioru ${ }^{556}$. Poniewaz brak mu było potrzebnej sankcji karnej, Innocenty III na soborze lateraneńskim III $w$ r. 1179 nakazał tych dziekanów, którzy by zwlekali z przyjęciem święceń kapłańskich, usuwać ze stanowiska i powierzać je księżom dającym rękojmię należytego wywiązywania się z przyjętych obowiązków ${ }^{557}$.

Surowiej postąpiono ze sprzedawaniem urzędu dziekańskiego. Gdy synod odprawiony w Poitiers w r. 1078 polecal jedynie pozbawiać tego urzędu kapłanów, co je nabyli za pieniądze ${ }^{558}$,

$55 \check{1}$ Por. Hinkmar, arcybiskup z Reims, Capitulà archidiaconibus presbyteris data, z r. 877, kan. 13. Mig n e, P. L., t. 125, kol. 802-804.; oraz zwłaszcza c. $7, \S 6, \mathrm{X}$, de officio archidiaconi, I, 23 , którego twórcą jest Innocenty III (1198-1215 r.).

Јă2 Syn. odprawiony $w r .1078$ w Poitiers (conc. Pictavense), kan. 2. IM a n s i, t. 20, kol. 498. Por. także syn. odbyty w Tours w t. 1163, kan. 7 (MI a n s i, t. 21, kol. 1178), oraz syn. odprawiony $\mathrm{w}$ Rouen (conc. Rotomagense) w r. 1231, kan. 24 (M a n s i, t. 23, kol. 216).

${ }_{553}$ Syn. odbyty $w$ Reims (conc. Remense) $w r .1131$, kan. 8. M a n si, t. 21, kol. 459-460.

${ }_{351}$ Nosi on nazwę ,conc. Claromontanum".

ธ̄̄5 Syn. klaromontański (conc. Claromontanum) z r. 1095, kan. 3. M a n s i, t. 20. kol. 817.

- $5 \overline{5} 6$ Zob. c. I, D. 60.

ว̆ธ Kan. 3 tegoż soboru. M a n s i, t. 22, kol. 219.

558 Syn. odbyty $w$ Poitiers (conc. Pictavense) w r. 1078, kan. 2, przyt. w odn. 184. 
sobór lateraneński II z r. 1139, utrzymując $\mathrm{w}$ mocy to zarządzenie, obostrzył je karą infamii, mająca dotykać tak sprzedawce, jak kupującego i pośrednika ${ }^{559}$, sobór zaś lateraneński III z r. 1179 wprost pozbawiał biskupów możności obsadzania dekanatów wakujących na skutek popełnionej przez nich symonii ${ }^{560}$. To nie przeszkadzało, że powyższy przepis $w$ niektórych diecezjach godzono $\mathrm{z}$ praktyką pobierania pewnych opłat kancelaryjnych $\mathrm{z}$ okazji mianowan dziekańskich ${ }^{561}$.

Dla zamknięcia drogi wszelkim wykroczeniom i zapewnienia doboru odpowiednich ludzi wspomniany sobór lateraneński III postanowił, by na dziekanów powoływano tylko tych księży, którzy ukończyli 25 rok życia, posiadają odpowiednią wiedze, odznaczają się nienagannymi obyczajami i wykazują zdolności kierownicze ${ }^{562}$.

Dodać należy, że w podobnym celu zaczęto od dziekanów wymagać, aby przy obejmowaniu urzędu składali przysięgę na wierność spełnianym przez siebie obowiązkom ${ }^{563}$.

$\mathrm{Na}$ pomniejszenie uprawnień dziekańskich wpłynął jednocześnie nieprzychylny dla nich zwyczaj, który przecież obok powszechnego prawa pisanego mial tutaj najwięcej do powiedzenia ${ }^{564}$. Mianowicie, podobnie jak w odniesieniu do archidiakonów, również w stosunku do dziekanów spadkobiercami

${ }_{558}$ Kan. 2 tegoż soboru. Mansi, t. 21, kol. 526.

560 Kan. 15 tegoż soboru. IMansi, t. 22, kol. 226.

561 Por. np. syñ. odbyty $w$ Rouen (conc. Rotomagense) W r. 1231, kan. 24. Mansi, t. 23, kol. 216.

562 Kan. 3 tegoż soboru. MI a n si, t. 22, kol. 219. Por, także przyt. $w$ odn. 553, kan 8. synodu odbytego $w$ Reims $w$ r .1131, a zwlaszcza syn. odprawiony w Rouen (conc. Rotomagense), kan. 15. Mansi, t. 20, kol. 38.- W szczególny sposób mieli biskupi zwracać uwagę, by kandydaci na dziekanów byli wolni od wady chciwości. Już Hinkmar, arcybiskup z Reims (um. 882), kładzie na to ogromny nacisk, czego dowodem jego list 52. Migne, P. L., t. 126, kol. 273.

${ }_{563}$ Por. np. Syn. lambeteński z r. 1281, kan. 12 (przyt. w odn. 659); syn. odprawiony $w$ Rouen w r. 1231, kan. 24 (przyt. w odn. 541); oraz syn. londyński z r. 1108, kan. 8 (przyt. w odn. 548).

564 B a rbosa A., dz. c., t. 1, s. 293.; Ferraris F. L., dz. c., t. 1, s. 404 ; oraz Wernz-Vid a 1 , dz. c., t. 2, s. 767. 
wielu ich przywilejów okazali się wprowadzeni świeżo i znani nam już umyślni urzędnicy, całkowicie od woli ordynariusza uzależnieni. Po raz pierwszy spotykamy się z nimi w w. XII. Początkowo noszą niezdecydowaną nazwę oficjałów, lub wikariuszów generalnych o uprawnieniach dość różnorodnych. Ürzędnicy ci powoli, lecz stale przejmują z rąk archidiakonów i dziekanów ich władzę, zwłaszcza z dziedziny spraw małżeńskich i karnych, by w koncu utworzyć dwie odrębne instytucje upoważnione do kierowania $\mathrm{w}$ imieniu ordynariusza całokształtem zagadnień bądź administracyjnych, bądź sądowych ${ }^{565}$.

Przysłowiowym gwoździem do trumny tak dla archidiakonów ${ }^{566}$; jak i dla dziekanów okazal się sobór trydencki. By ujednolicić prawodawstwo $\mathrm{w}$ odniesieniu do tych ostatnich, ojcowie soborowi nadali zarządzeniom synodów partykularnych moc wiążąca prawa powszechnego ${ }^{567}$. W szczególności postanowili, że sprawy małżenskie i karne wyjmuje się spod ich władzy i zastrzega biskupowi ${ }^{568}$. Do niego również należy badanie, czy duchowni przestrzegają kanonów kościelnych, zwłaszcza co do celibatu, oraz karanie winnych ${ }^{569}$. Jemu jedynie przysługuje możność korzystania $w$ sposób roztropny $z$ prawa nakładania ekskomuniki ${ }^{570}$. On wreszcie powinien osobiście, lub za pośrednictwem wikariusza generalnego, czy innego upoważnionego dygnitarza wizytować corocznie parafie, co jednak nie przeszkadza, że i dziekani podobny obowiązek mają spełniać, o ile tylko zwyczaj im na to zezwala, maja każdorazowo zezwolenie władzy diecezjalnej, dobiorą sobie do pomocy sekretarza, wizytację przeprowadzą osobiście i w ciągu miesiąca zdadzą z niej ordynariuszowi sprawozdanie ${ }^{571}$.

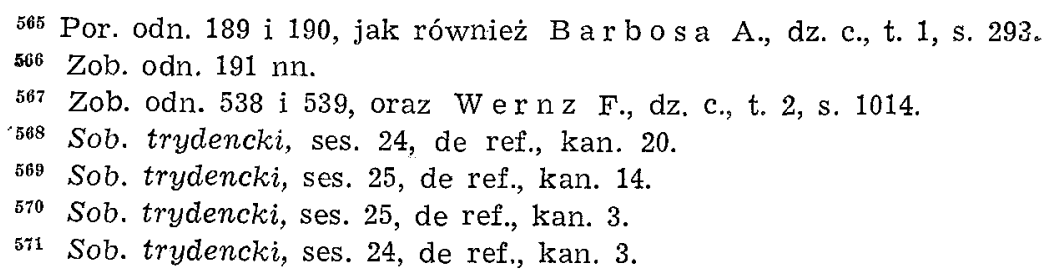


Ponieważ twórcy reformy trydenckiej zagadnienia dziekańskiego dotknęli raczej w sposób uboczny ${ }^{572}$, ich postanowienia w niedługim czasie musiały znaleźć wyjaśnienie i uzupełnienie. Już 11 grudnia $1598 \mathrm{r}$. wyszła w tym względzie dość szczegółowa decyzja św. Kongregacji Soborowej ${ }^{573}$, która ustaliła co następuje:

1. Dziekani nie posiadają właściwej i pełnej władzy jurysdykcyjnej, gdyż ta przysługuje jedynie biskupowi. W sprawach małżeńskich mogą jedynie zbierać informacje tak od stron, jak i świadków, ale w sposób całkowicie poza-sądowy, i nagromadzony materiał przesyłać do Ordynariusza ${ }^{574}$.

2. Nieposłusznych swym nakazom nie wolno im sądzić i karać, co nie przeszkadza, że powinni takich ludzi napominać, a rzecz całą pozostawić do ostatecznej decyzji władzy duchownej ${ }^{575}$.

3. Wszelkie nieporozumienia między duchowieństwem mają załatwić w sposób polubowny. O ile ich wysiłki nie odniosą pożądanego skutku, w sprawę wejrzy biskup i ją autorytatywnie rozsądzi ${ }^{576}$.

4. Jedynie w rzeczach drobnych moga rozstrzygac samodzielnie, ale tak, by ich zachowanie nie mialo formy aktu sądowego. Oczywiście, gdyby $w$ podobnych wypadkach otrzymali odpowiednie upoważnienie ze strony ordynariusza, wówczas wolno im wystąpić w charakterze sędziów delegowanych ${ }^{577}$.

Zasady powyższe, jako zbyt przykre dla dziekanów, nieprędko znalazły wśród nich należyty posłuch. Dla położenia kresu wszelkim wątpliwościom i ustabilizowania raz wprowadzonego porządku prawnego św. Kongregacja Soborowa aż dwukrotnie, bo 20 czerwea 1750 r. i 11 marca 1752 r., uroczyście przypom-

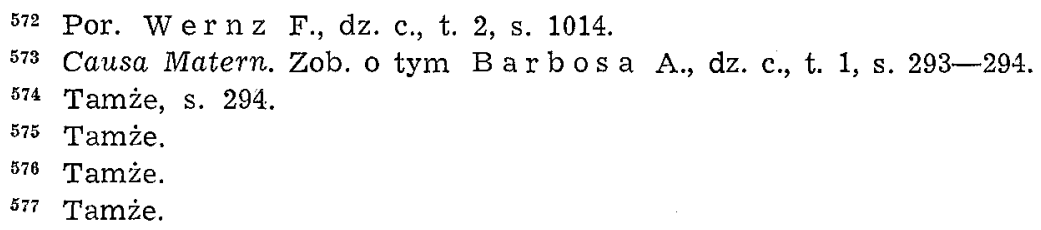


niała, że dziekani w swoich okręgach nie rozporządzają w ścisłym znaczeniu żadną władzą jurysdykcyjną, gdyż taką całkowicie i wyłącznie posiadają tylko ordynariusze ${ }^{578}$.

$\mathrm{Na}$ osłabienie autorytetu instytucji dziekańskiej, a nawet na czéściową zmianę jej nazwy $w$ dużym stopniu wpłynął arcybiskup Mediolanu św. Karol Boromeusz. Świadom zaniedbań i nadużyć, których dopuszczali się dotychczasowi dziekani, pragnąc zarazem podnieść znajomość prawa kościelnego oraz tylokrotnie podkreślaną przez Ojców soboru trydenckiego karność wśród duchowieństwa, już na pierwszym swoim synodzie mediolańskim odprawionym w r. 1565 polecił podległym sobie biskupom, by diecezje podzielili na pewną ilość okręgów i troskę nad nimi zlecili odpowiednio uzdolnionym i prawym kapłanom. Nowi ci urzędnicy mają się nazywać „vicarii foranei". Zadaniem ich będzie wspomagać biskupa w sprawowaniu przezen skutecznych rządów w diecezji. Mogą być mianowani spośród archiprezbiterów, zwanych gdzie indziej dziekanami, spomiędzy archidiakonów, lub w ogóle takich osób, które posiadają jakąś godność kościelną ${ }^{579}$. Wszyscy proboszczowie, nawet piastujący pewne urzędy duchowne, mają ich słuchać, oczywiście w granicach ściśle prawem określonych. Winni nieposłuszeństwa będą odpowiednio przez biskupa karani. Ten ostatni nie omieszka karcić ich samych jeśli będą źle spełniać swoje obowiązki. On również, kiedy zechce, ma prawo odwołać ich z urzędu ${ }^{580}$.

Szczególnym obowiązkiem wikariuszów foralnych było zwoływać co miesiąc $\mathrm{w}$ pewnym, za każdym razem zwykle innym miejscu swego okręgu zebranie wszystkich kapłanów trudniących się duszpasterstwem i to $\mathrm{z}$ zachowaniem następującego

578 A manieu A., Archiprêtre, j. w., kol. 1017-1018.

579 Syn. Mediolański I, cz. 2, kan. 29 (z r. 1565). M a n s i, t. 34, kol. 42. Encykl. Kość. Nowodworskiego, t. 1, s. 374, sv. archipresbiter, na powyższy temat tak pisze: „Sw. Karol Boromeusz zniósł zupełnie w swojej diecezji władzę dziekanów i na pierwszym swoim synodzie prowincjonalnym postawil na ich miejsce wikariuszów foralnych:

${ }_{580}$ Syn. Mediolański I $z$ r. 1565 , cz. 2, kan. 29. M a n s i, t. 34, kol. 43. 
porządku czynności ${ }^{581}$. Zebrani na kongregację duchownych w przeddzień zjazdu przystąpią do spowiedzi św.

Następnego dnia rano każdy z nich odprawi mszę św., by później o oznaczonej godzinie wziąć udział w uroczystej mszy św. odprawianej za zmarych, lub do Ducha św., w czasie której jeden $z$ kapłanów, uprzednio w tym celu wyznaczony przez wikariusza foralnego, wygłosi do zebranego ludu słowo boże.

Po nabożeństwie i procesji żałobnej dookoła Kościoła, polączonej $\mathrm{z}$ odśpiewaniem przepisanych modlitw uczestnicy zjazdu udadzą się na plebanię, gdzie spożyją skromne śniadanie.

Po czym przystąpią do obrad. Zasadniczym tematem rozważań mają być zagadnienia duszpasterskie oraz trudności związane $z$ praca na terenie parafii. Właśnie obecność wielu światłych i doświadczonych kolegów ułatwi właściwe rozwiązanie niejednego, bardziej skomplikowanego wypadku. Nadto wikariusz foralny odczyta zebranym liste rezerwatów biskupich i papieskich, jak również fragment statutów ogłoszonych na ostatnim synodzie prowincjonalnym, czy też diecezjalnym oraz przy pomocy odpowiedniego podręcznika wyjaśni pare spraw dotyczących sumienia.

W szczególności jednak tenże wikariusz zbada, czy podlegli mu duchowni prowadzą życie zgodnie $z$ przepisami Kościoła i czy należycie spełniają swoje obowiązki. Dowie się, czy jaki kapłan przez swe karygodne niedbalstwo nie pozbawia wiernych możności wysłuchania obowiązkowej mszy św., lub innych nabożeństw; czy uiszcza nałożone przez władze diecezjalne składki przeznaczone na wsparcie zubożałych i zniszczonych kościołów; czy prowadzi księgi prawem przepisane oraz czy wciela w życie wszystkie postanowienia synodalne.

Oczywiście porządek dzienny nie może pominąc aktualnych zarządzeń biskupich.

W wolnych wnioskach należy uwzględnić to wszystko $z$ dziedziny duszpasterskiej, co budzi jakiekolwiek wątpliwości i wymaga autorytatywnego wyjaśnienia ze strony władzy diecezjal-

581 Tamże, kol. $42-43$. 
nej, lub też dla niej samej może posiadać jakąkolwiek wartość. $Z$ odbytego zebrania powinien być spisany dokładny protokół i w odpisie odesłany do biskupa.

Poza odbywaniem miesięcznych kongregacyj wikariusze foralni mają obowiązek za każdą bytnością $\mathrm{w}$ stolicy swej diecezji nawiedzić ordynariusza i powiadomić go o każdym znamiennym wypadku, który się wydarzył na terenie ich okręgu.

Instytucja wikariuszów foralnych zdała egzamin praktyczny i dla swych zalet ogromnie się w Kościele upowszechniła. Doszło do tego, że powoli całkowicie zastapiła dawnych archiprezbiterów wiejskich ${ }^{582}$, czyli dziekanów, przechodzących współcześnie głębokie przeobrażenia wewnętrzno-ustrojowe. Nowy Kodeks Prawa Kanonicznego zna już tylko wikariuszów foralnych ${ }^{583}$, choć dla określenia podległych im okręgów obok nowej zachował jeszcze dawną nazwę dziekanatu i archiprezbiteratu ${ }^{584}$.

Ponieważ zarządzenia papieskie i biskupie w okresie przedkodeksowym pozbawiły ostatecznie dziekanów wszelkiej władzy jurysdykcyjnej, trudno się w nich dopatrzyć charakteru prawdziwych, zwłaszcza wyższych dostojników ${ }^{585}$.

Jak chcą niektórzy, instytucja dziekanatu przed Kodeksem $\mathrm{w}$ ogóle nie była ani beneficjum, ani oficjum o ustalonym zakresie praw i obowiązków, lecz jedynie pewnego rodzaju godnością, całkowicie uzależnioną od biskupa i przez niego wyposażoną $w$ niektóre uprawnienia dla sprawniejszego kierowania diecezją ${ }^{586}$.

Inaczej rzecz się przedstawia w świetle przepisów Kodeksu Prawa Kanonicznego. Choć obecnie treść władzy dziekańskiej zasadniczo pokrywa się $\mathrm{z}$ jej uprawnieniami przedkodekso-

582 Ferraris F. L., dz. c., t. 1, s. 402.

583 Por. tytuł kan. 445 nn. Kod. Pr. Kan. (,De vicariis foraneis").

584 Kan. 217, \& 1 Kod. Pr: Kan.

585 Schmalzgrueber F., dz. c., t. 2, s. 141-142. Por. także Ferraris F. L., dz. c., t. 1, s. 402, gdzie autor powoluje się na Rotę, part. XVII recent., decis. 195 , n. 18, i part. XIX, tom. 2, decis. 496 , n. 44.

580 L a u reatius J., Institutiones iuris ecclesiastici. Friburgi Brisgoviae 1908 , s. 169. 
wymi i sprowadza się głównie do nadzoru nad wykonywaniem przez duchowieństwo kanonów kościelnych ${ }^{587}$, ma ona zasad.niczo inny charakter. Mianowicie dziekanat, nadal nie będąc beneficjum i nie posiadając żadnej jurysdykcji ${ }^{58}$ jest $w$ pełnym słowa znaczeniu oficjum, czyli urzędem $z$ władzą zwyczajną przez prawo powszechne określoną, której ciągłość związana jest nie $z$ osobą, lecz $z$ samą godnością ${ }^{589}$. To nie przeszkadza, że dziekani oprócz czynności, przysługujących im na podstawie Kodeksu, spełniać mogą takie, które im zleci ich własny biskup ${ }^{590}$.

\section{Archiprezbiterzy okręgowi, czyli dziekani $w$ polskim prawie kościelnym}

A. Powstanie i rozwójurzedu dziekańskiego

Jeśli początki archidiakonatu w Polsce nie są należycie wyświetlone ${ }^{591}$, to tym bardziej do zagadnień spornych należeć będzie sprawa pierwotnej historii naszego dziekanatu wiejskiego.

Trudno przypuścić; by dziekani istnieli od samego zarania polskiego Kościoła z tej prostej przyczyny, że byli niepotrzebni. Dla braku odpowiednio rozbudowanej sieci kościołów i kaplic oraz $\mathrm{z}$ powodu nielicznego duchowieństwa organizacja życia religijnego przez pewien czas musiała nosić charakter misyjny i odznaczać się prostotą, a przez to i niezupełnością niektórych urzędów ${ }^{502}$.

Mam tu na myśli właściwą Polskę, gdyż kresy jej południowe, jak ziemia Wiślan i Ślęzan, stanowiąca terytorium póź-

587 Zob: kan. 447 Kod. Pr. Kan. oraz nn. cyt. w odn. 1; jak również

Grabowski I., Prawo kanoniczne. Warszawa 1948, s. 241.

588 Por. Gr a bow ski I., tamże.

589 W e r n z-Vid a l, dz. c., t. 2, s. 767.

590 Kan. 447, § 1 Kod. Pr. Kan.

501 Por. odn. 201

592 Silnicki T., Organizacja archidiakonatu, s. 77-78. 
niejszego biskupstwa krakowskiego i wrocławskiego, już wcześniej uległa chrystianizacji ${ }^{\mathbf{5 9 3}}$. Urząd archiprezbiterów czyli dziekanów wiejskich mógł się okazać przydatny i nawet konieczny z chwilą gdy liczba świątyń i pracującego przy nich duchowieństwa odpowiednio wzrosła, co w ogromnym stopniu musiało utrudniać utrzymanie właściwej kontroli nad różnorodnym i bogatym życiem kościelnym ${ }^{594}$. Czujność archidiakonów okręgowych, jako z natury niezbyt licznych, sprostać za-daniom nie potrafiła. Zresztą pojawiają się oni u nas dość późno, bo dopiero pod koniec XII w. ${ }^{595}$. Tymczasem, pozostawiając zresztą na uboczu zagadnienie początku parafii $w$ naszej Ojczyźnie jako sporne w nauce ${ }^{596}$ skoro zważymy, że mimo nie-

593 Zob. np. S z c ześn i a k W., dz. c., t. 2, s. 119-120; B u czek K., j. w., s. 191 nn., omawiający szczególnie zagadnienie początkowej organizacji kościelnej w późniejszej diecezji krakowskiej; Silnicki T., Organizacja archidiakonatu, s. 112-114, przyt. w odn. 244; oraz A br ali a m W., Organizacja Kościola $w$ Polsce, s. 1 nn:

594 Por. np. odn. 478.

595 Por. odn. 244.

596 Zob. Krynicki W., dz. c., t. 1, s. 236, odn. 3. Mówiąc nawisem, Abrah am W., Organizacja Kościola $w$ Polsce, s. 163, utrzy.muje: „Jako pewnik przyjąć należy, że za Krzywoustego jeszcze w Polsce podziału na parafie i okręgi plebanalne nie było ... Wskutek ... przywilejów biskupich przekształcały się w drugiej wieku XII polowie kapelanie w parafie ... W miastach znaczniejszych zapewne wcześniej już osobne parafie powstały, być może, że jeszcze nie ze wszystkimi prawami"... Kujot S., Kto zatożyt parafie w dzisiejszej diecezji chetmińskiej? Toruń 1903, s. 36, jak również Z a chorowski S., Poczatki parafii polskich, s. 283 i 286, kościolom noszącym tytuł „ecclesia”, a spotykanym już od zarania chrześcijaństwa w Polsce, przyznają charakter w?aściwych kościołów parafialnych, choć bez ściśle określonego okręgu. Kłodziński A., w recenzji o pracy Zachorowskiego na temat początków parafii w Polsce. Przegląd Powszechny 31 (1914), t. 72, s. 415, tak w krótkości rzecz całą ujmuje: „Każda „ecclesia”, spotykana W źródłach polskich z XI i XII wieku może uchodzić za zarodek parafii, ale nie tworzy go ,capella", która podobnie jak na Zachodzie, tak $i \mathrm{w}$ Polsce posiada mniejsze znaczenie niż „ecclesia" w organizacji kościelnej”. Jak niektórzy autorzy różnią się poglądami na sposób powstawania parafii $w$ Polsce, zob. B a $\mathrm{J}$. R. Relationes inter religiosos et episcopum. Cracoviae 1940, s. 14. 
licznych wzmianek o kościołach polskich z XI i XII w. ${ }^{597}$ wiadomości o miejscach kultu z pierwszego okresu naszej historii doszły do nas dzięki przypadkowo sporządzonym zapiskom ${ }^{598}$, względy zaś ewangelizacyjne domagały się poza katedrą biskupią innych jeszcze posterunków pracy misyjnej ${ }^{599}$ od niej nawet starszych ${ }^{600}$, dojść musimy do wniosku, iż kościołów i kaplic już dość wcześnie, jak mówi Kujot, ,nie brakło... po kraju" ${ }^{601}$.

Ktoś nad nimi musial roztoczyć konieczny dozór i opiekę.

W Kościele polskim względnie szybko rosnącym ,nie było ani czasu, ani warunków na wytworzenie się różnolitych instytucji i pojęć prawnych... I tak nie było w Polsce archi-

597 A b r ah am W., Organizacja Kościola $w$ Polsce, s. 161, odn. 1, wylicza 4 kościoły, nie będące katedrami biskupimi: w Gieczu z r. 1309 , w Spicimierzu z r. 1108 oraz w Sandomierzu i Zawichoście z r. 1148. K u jot S., Kto założyz parafie $w$ dzisiejszej diecezji chetmińskiej, s. 34, oprócz wspomnianych kościolów wymienia następujące: kościól św. Michała w Krakowie z r. 1148, kolegiata N.M.P. w Eęczycy z r. 1136, kościół św. Idziego we Włocławku z r. 1145, oraz z tegoż roku kościół we wsi Waśniów pod Opatowem, w Korczynie i kościół N.M.P. w Łęczycy na górze, nadto z r. 1065: kościół św. Wawrzńca w Plocku, św. Jana we Włocławku, św. Jakuba $w$ Mogilnie i inny jakiś kościól pod wezwaniem św. Klemensa.

${ }^{598}$ Zob. Kujot S., Kto zało $\dot{z} y$ parafie $w$ dzisiejszej diecezji chełminskiej, s. 34, Z a ch o rowski S., Poczatek parafii $w$ Polsce, s. 281, słuszną robi w związku z tym uwagę: ,... stosunki były skomplikowane, co pociąga za sobą ... wniosek, że rozwój daleko wyprzedza najstarsze nawet wzmianki dokumentowe".

${ }_{599}$ A braham W., Organizacja Kościoła $w$ Polsce, s. 160-161; K ujot S., Kto zatożyi parafie $w$ dzisiejszej diecezji chełminskiej, s. 35-36; Zachorowski S., Poczatek parafii $w$ Polsce, s. 282-283.

600 Por. np. Kujot S., j. w., s. 36: ,... pierwsze kościoły po grodach innych wydatniejszych osadach współcześnie z katedrami biskupimi, nawet prędzej jeszcze od nich zakładane być mogły".

${ }_{601} \mathrm{~K} u j \mathrm{j} 0 \mathrm{t}$ S., j., w., s. 36 . Siln icki T., Organizacja archidiako$n a t u$, s. 63 robi następującą uwagę: ,... instytut parafịi jako powszechny i bardziej konieczny od archidyakonatu musiał zaistniec co najmniej razem z nim, a wolno przypuszczać, że nawet wcześniej i że właśnie zorganizowanie sieci parafialnej wywolało potrzebę stworzenia liczrych i stałych organów kontroli, którymi były archidyakonaty". Zob. także tekst do odn. 246 . 
prezbyterów $\mathrm{w}$ znaczeniu pierwotnych plebanów macierzystych kościołów nie było $\mathrm{w}$ każdym razie przed rozpoczęciem ewolucji w archidiakonacie, a o tych chrzcielnych kościołach i okręgach z nimi złączonych nic pewnego powiedzieć nie potrafimy" 602 .

Potrzebny pomocniczy organ kontrolny, podobnie jak w sprawie archidiakonów okręgowych ${ }^{603}$, stworzyli na skutek potrzeby biskupi i to prawdopodobnie pod wpływem wzorów obcych: włoskich od czasów Chrobrego (r. 992-1025), od czasów zaś Kazimierza Odnowiciela (r. 1038-1058) - francuskich, które biorą górę nad prądami niemieckimi ${ }^{604}$ i które u nas, jak już wiemy, zdecydowanie zaważyły na historii polskiego archidiakonatu ${ }^{605}$. Nowa instytucja - to archiprezbiterzy, w w. IX zaczynający zdobywać znaczenie we Włoszech ${ }^{606}$ i szybko dochodzących do szczytu rozwoju we Francji, gdzie już $\mathrm{w}$ połowie tegoż wieku otrzymują nazwę dziekanów wiejskich ${ }^{607}$.

W Polsce, podobnie zresztą jak we Francji 608 archiprezbiterzy czyli dziekani pojawili się prawdopodobnie przed archidiakonami okregowymi, gdyż tu i tam grały rolę przyczyny podobne, a mianowicie konieczność roztoczenia opieki nad stale wzrastającą liczbą kościołów w ogóle, a parafialnych w szcze-gólności ${ }^{609}$. Najdawniejsze znane nam polskie synody milczą o nich zapewne dlatego, ,że znano obowiązki dziekanów ze zwyczaju, lub że biskupi mało na nich liczyli, jako mniej oświeconych, a cały ciężar pasterskiej czynności składali na archidiakonów, jako zdolniejszych" ${ }^{610}$.

602 Silnicki T., j. w., s. 78.

603 Zob. wyżej tekst do odn. 246.

${ }_{604}$ Por. np. Zachorowski S., Rozwój $i$ ustrój kapitut polskich w wiekach średnich. Kraków 1912, s. 70.

${ }_{005}$ Por. odn. 230.

606 Zob. odn. 97.

607 Zob. odn. 101.

608 Zob. odn. 111.

609 Por. odn. 233.

${ }^{610} \mathrm{Chodyński}$ Z., Dziekan wiejski. Enc. Kość. Nowodworskiego, t. 4 , s. 454 . 
Po raz pierwszy wyraźną wzmiankę o archiprezbiterach, nazwanych również dziekanami, spotykamy nie $\mathrm{w}$ statutach łęczyckich arcybiskupa Jakuba Swinki z r. 1285, jak chce Zenon Chodyński ${ }^{611}$, a za nim profesor Abraham ${ }^{612}$ i Jan Fijalek ${ }^{613}$, lecz w statutach synodu prowincjonalnego odprawionego, zgodnie ze znaczeniem ówczesnego Kościoła śląskiego ${ }^{613 a}$, we Wrocławiu w r. 1248 pod przewodnictwem archidiakona leodyjskiego Jakuba, późniejszego papieża Urbana IV. Legat ten papieski w kanonie 1 swych postanowień wzywa zebranych biskupów by po powrocie do swych diecezji w ciągu miesiąca przeprowadzili osobiście wizytację duchowienstwa pracującego przy katedrze, zatrudnionego zaś przy innych kościołach przez archidiakonów, albo takich kapłanów, których za odpowiednich sami uznają. O ile by się okazalo, że kto $z$ duchownych żyje w konkubinacie, nie patrząc na to, czy jest nim archidiakon, dziekan, archiprezbiter, lub jakikolwiek inny du-chowny, mają mu nakazać, aby nałożnicę $w$ ciągu miesiąca od siebie oddalił, w wypadku zaś nieposłuszeństwa postąpić $\mathrm{z} \operatorname{nim} \mathrm{w}$ sposób przewidziany przez kanony ${ }^{614}$.

$\mathrm{W}$ związku $\mathrm{z}$ powyższym przepisem należy zwrócić uwage na okoliczności następujące:

1. Legat papieski mówi o dziekanach i archiprezbiterach tak, jakby te godności nie zawsze były piastowane przez tę samą osobę, gdyż wymienia ją oddzielnie.

2. Są oni sobie pokrewni: stoją obok siebie złączeni spójnikiem innym, niż spójnik użyty przy wyliczaniu pozostałych stopni hierarchicznych.

3. Prawodawca nie wymienia żadnych uprawnień przysługujących dziekanom lub archiprezbiterom. Widocznie sprawa

${ }_{111}$ Chodyński Z., Dziekani w Polsce. Tamże.

612 A b r a am W., Organizacja Kościola w Polsce, s. 158.

${ }_{113} \mathrm{Fijałek} \mathrm{J.,} \mathrm{Najstarsze} \mathrm{statuty} \mathrm{synodalne} \mathrm{krakowskie} \mathrm{biskupa}$ Nankera $z 2$ pazdz. 1320 r. Kraków 1915, s. X-XT.

613a Por. np. B aran C. C., Sprawy narodowościowe u Franciszkanów śląskich $w$ XII $w$. Studia historico-ecclesiastica, t. 9. Warszawa 1954 , s. 128.

614 H u be R., j. w., s. 18. 
ta była od dawna uregulowana przez zarządzenia biskupie, czy też na podstawie zwyczaju.

4. Legat piętnuje zdrożności, którym jedni i drudzy wraz z innymi przedstawicielami niższego i wyższego duchowieństwa ulegli, co wskazywałoby na przebytą już pewną ewolucję.

Względy powyższe pozwalają wysnuć wniosek, że urząd dziekana i archiprezbitera w pierwszej połowie XIII w. w Polsce to instytucja dość stara, ulegająca nawet częściowo zwyrodnieniu. Nie jest ona zbyt dawna, kiedy obie nazwy zdaja się wykazywać pewną różnicę, choć dążą do całkowitego zespolenia się z sobą.

$\mathrm{Z}$ powodu braku odpowiednich danych źródłowych nie można bliżej określić czasu, kiedy została ona wprowadzona do ustroju naszego Kościoła i jaki pierwotnie miała charakter. Ogólnie się przyjmuje, że początkiem swym sięga XII w. ${ }^{615}$. Może zawdzięczać swe powstanie znakomitemu reformatorowi karności kościelnej w Polsce arcybiskupowi gnieźnieńskiemu Henrykowi Kietliczowi (r. 1199-1219) ${ }^{616}$, lub jednemu z legatów papieskich ${ }^{617}$ : Piotrowi z Kapui (r. 1197), kardynałowi Janowi Malabranca (r. 1189), czy też kardynałowi Gwido (r. 1148), dążącym do odrodzenia polskiego kleru ${ }^{618}$.

Nie jest wykluczone, że sięga ona nawet XI w., w szczególności zaś czasów Bolesława Śmiałego (r. 1058-1079), kiedy to według np. Kujota miał się w Polsce dokonać podział diecezji na parafie ${ }^{619}$, a może nawet czasów Kazimierza Odnowiciela

615 Tak utrzymuje Zenon Chodyński w swej pracy o dziekanach w Polsce. Encykl. Kość. Nowodworskiego, t. 4, s. 454, a za nim Henryk Przeź dziecki, Dziekani w Polsce. Podręczna Encykl. Kość., t. 9-10, s. 265.

616 Zob. o nim np. Grom nicki T., dz. c., s. 25-34.

617 Zob. o nich np. Gromnicki T., dz. c., s. 16-25.

618 Por. tekst do ođn. 415 i 416.

619 Zob. Krynicki W., dz. c., t. 1, s. 236, odn. 3. gdzie cytuje Kujota S., Dzieje Prus Królewskich. Toruń 1913, s. 367. Stanowisko takie Kujot zajmuje widocznie ze względu na list papieża Grzegorza VII do Bolesława Śmiałego, w którym to liście papież wyraźnie wspomina 
(r. 1041-1058), za którego panowania, zdaniem niektórych, mieli się u nas ukazać archidiakoni okręgowi ${ }^{620}$. Pokrywałoby się to ze stanowiskiem wielu badaczy, dopatrujących się pewnych analogii w stosunkach panujących w w. XI i XII w Polsce $i$ we Francji ${ }^{621}$, gdzie przecież instytucja dziekana powstała $\mathrm{i}$ była $\mathrm{w}$ tym okresie $\mathrm{w}$ pełnym rozkwicie ${ }^{622}$, jak również z faktem, że typ polskiego pierwotnego archidiakona by wzorowany na prawie kościoła francuskiego ${ }^{623}$.

Nieznany autor „Vita minor" św. Stanisława Szczepanowskiego (r. 1072-1079) dziełka powstałego wprawdzie na początku XIII w., ale opartego na dokumentach daleko wcześniej. szych, początek urzędu dziekańskiego, przynajmniej w diecezji krakowskiej, każe odnieść do okresu rządów naszego pierwszego męczennika ${ }^{24}$. W świetle tego, co wiemy o ówczesnych polskich stosunkach ${ }^{625}$, zwłaszcza o stosunkach panujących $w$ najdalej wysuniętej na południe naszej diecezji ${ }^{\mathbf{6 2 6}}$, przy uwzględnieniu charakteru św. Stanisława i jego działalności ${ }^{627}$, zdanie powyższe nie jest pozbawione pewnych podstaw.

Nie rozstrzygając, kiedy dokładnie dziekani i archiprezbiterzy okręgowi zostali przeszczepieni $z$ Zachodu na grunt ojczysty, wnosić można, że w pierwszej połowie XIII w., tj. w chwili pojawienia się pierwszej wzmianki, byli uważani praktycznie za jeden i ten sam stopień hierarchiczny, choć odczuwano jeszcze niewielką między nimi różnicę.

Obowiązki ich w tym okresie odpowiadały zapewne stosun-

o „wielkiej liczbie wiernych" (slowa te zob. u Gromnickiego T., dz. c., s. 13, oraz IM a n si, t. 20, kol. 182).

$620 \mathrm{~K}$ a kowski A., Archidiakon $i$ archidiakonaty $w$ Polsce. Podręczna Encykl. Kość., t. 1-2, s. 309 (zob. odn. 341).

${ }^{821}$ Por. np. Siln i cki T., Organizacja archidiakonatu, s. 19, odn. 1, gdzie autor powołuje się na Smolkę, Bobrzyńskiego i Abrahama.

622 Por. odn. 479.

623 Por. odn. 230.

624 Zob. odn. 244.

625 Zob. np. odn. 619.

${ }^{626}$ Zob. odn. 593.

627 Por. np. K r yni cki W., dz. c., t. 1, s. 229-233. 
kom francuskim, przynajmniej o wiek wcześniejszym, wobec znanego naszego opóźnienia się $w$ rozwoju i naśladownictwa Zachodu ${ }^{628}$. Zarazem musiały się one mieścić $w$ ramach prawa powszechnego, które przez listy papieży i legatów Stolicy Apostolskiej, wysyłanych dla odbywania synodów krajowych oraz duchownych, przybywających do nas z Zachodu W W. XII i XIII, coraz bardziej się upowszechniało, oczywiście przy uwzględnieniu stosunków miejscowych ${ }^{629}$. Potwierdzeniem tego jest zarządzenie arcybiskupa Jakuba Świnki, ogłoszone w r. 1285 na synodzie łęczyckim i uważane przez niektórych za pierwszą jaskółkę o dziekanach w naszym ustawodawstwie synodaInym ${ }^{630}$. Mianowicie w statucie $40-y m$ swojego synodu wspomniany arcybiskup nakazuje, by archidiakoni, lub też dziekani o wykroczeniach podwładnego sobie duchowienstwa wiernie donosili swemu arcybiskupowi, który winnych ma odpowiednio ukarać ${ }^{331}$.

Mimo, zdawałoby sie, niezbyt rozległej władzy, dziekani stanowią poważną godność $w$ diecezji, gdyż tenże arcybiskup w liście pisanym w r. 1297 do swego imiennika, biskupa we Wrocławiu, poleca okładać interdyktem tak dekanaty, gdzie dokonano zabójstwa dziekana, lub napaści na niego, jak również to miejsce, dokąd go uprowadzono ${ }^{632}$.

Zarazem $\mathrm{z}$ wymienionego listu dowiadujemy się, że dziekani podlegają bezpośrednio władzy archidiakona, ponieważ pod jego kierownictwem maja sprawować zarząd parafii $w$ wypadku śmierci beneficjata. Gdyby ten nie pozostawił żadnego testamentu i jego parafia znajdowała się poza miastem biskupim, przejmujący jej kierownictwo dziekan wszystkie dochody kościelne, po odtrąceniu części należnej na utrzymanie wika-

628 Por. odn. 228 i 229 oraz Silnicki T., Organizacja archidiakonatu, s. 19.

${ }_{629}$ Zob. odn. 625 i 626 oraz Z a chorowski S., Sqdy synodalne $w$ Polsce. Odbitka z t. 54 rozpraw Wydziału hist.-filoz. Akad. Umiej. w Krakowie. Kraków 1911, A.U., s. 20, ođn. 4.

${ }_{630}$ Zob. odn. 611 i 612.

631 II ube R., j. W., s. 179.

639 Hube R., j. W., s. 182, odn。 1. 
riusza przy świątyni, przeznaczy na spłacenie długów zmar-łego, na nabożeństwo żałobne za jego duszę oraz na inne pobożne cele ${ }^{633}$.

Może kto zapytać, czy poza przytoczonymi tekstami legata Jakuba i arcybiskupa Jakuba Świnki nie należy dziekanów, lub archiprezbiterów dopatrywać się $\mathrm{w}$ zastępcach archidiakonów, o których to zastępcach synody XII w. niejednokrotnie wspominają ${ }^{634}$. Na pytanie to należy odpowiedzieć w zasadzie twierdząco, choć teksty najdawniejsze wyraźnie podkreślają, że ów zastępca winien być ,vicarius idoneus" i zazwyczaj wymieniają go w liczbie pojedyńczej, mówiąc o całym archidiakonacie, albo niekiedy o diecezji. Należy przecież pamiętać, iż w licznych wypadkach, szczególnie w latach późniejszych, gdy dziekani łącznie ze swymi bezpośrednimi przełożonymi, a nawet ich kosztem, uzyskają większe uprawnienia, które zwłaszcza dla tych ostatnich staną sie przyczyną różnych nadużyć ${ }^{635}$, wielu archidiakonów szukać będzie zastępstwa i wyręki dziekanów, co w koncu, mianowicie w statucie 7 synodu prowincjonalnego kaliskiego, odprawionego przez arcybiskupa Jarosława w r. 1357, znalazło urzędowe potwierdzenie dla całej Polski ${ }^{636}$. Stało się to pod wpływem stosunków z Zachodem, gdzie przystąpiono do ograniczania władzy archidiakonów ${ }^{637}$, z tą różnicą, że u nas nie było przyjęte, by dziekani całkowicie ich zastępowali w zakresie sądownictwa kościelnego ${ }^{638}$.

${ }^{633} \mathrm{H}$ u be R., j. w., s. 181-182.

634 Por. np. syn. sieradzki arcybiskupa Pełki z r. 1233, stat. 4, cyt. w odn. 398. syn. wrocławski legata Gwidona z r. 1266, stat. 1. H u be R., j. W., s. 59; oraz tegoż synodu stat. 8. Tamże, s. 67 .

635 Por. tekst do odn. 357.

638 H u be R., j. w., s. 211. Zresztą skądinąd wiemy, że „dziekan... był pomocnikiem archidiakona $i$ te same co on miał obowiązki, lecz te cgraniczaly się li tylko na jego dekanat" (Chodyński Z., Poczqtek: dziekanów $w$ Polsce. Encykl. Kość., Nowodworskiego, t. 4, s. 454). Por. także np. odn. 328.

637 Zob. odn. 187.

638 Por. tekst do odn. Z a chorowski S., Sady synodalne $w$ Polsce, s. 22 ; oraz niżej na swoim miejscu. 
Wyrazem rosnącego znaczenia dziekanów jest zlecenie, dane im przez biskupa wrocławskiego Henryka z Wierzbna w r. 1305, aby $w$ ciągu miesiąca po odbyciu synodu diecezjalnego odpisy jego uchwał otrzymane od archidiakona przekazali podwładnym sobie proboszczom ${ }^{639}$. Według Nankera, znanego reformatora prawodawstwa kanonicznego diecezji krakowskiej na początku XIV w. i w omawianej sprawie wiele mającego do powiedzenia ${ }^{640}$, dziekani mogą te odpisy otrzymywać bez-pośrednio $\mathrm{w}$ Kurii w ciągu dwu miesięcy dla rozprowadzenia ich przez następne 3 miesiące między duchowieństwem ${ }^{641}$.

Tenże Nanker, jakby uzupełniając znane nam zarządzenie arcybiskupa Jakuba Świnki z r. $1279^{642}$, w wypadku ciężkiej i niebezpiecznej choroby kapłana poleca dziekanom zaopiekować się nim i jego mieniem, należącym przecież do biednych. $\mathrm{Na}$ pierwszą wieść o śmiertelnej niemocy podległego sobie księdza, głosi jego statut $41^{643}$, dziekan wyśle do niego dwóch, iub trzech najbliżej mieszkających kapłanów. Ci po przybyciu sporządzą dokładny spis całego jego majątku. W wypadku śmierci chorego sam dziekan zajmie się pogrzebem i wypelnieniem woli zmarłego wyrażonej w testamencie. Dopilnuje, by długi nieboszczyka zostały spłacone, legaty zabezpieczone oraz pewna część przekazana następcy. Gdyby kto, nie wyłączając patrona kościoła, próbował siłą przywłaszczyć sobie jaką rzecz $\mathrm{z}$ pozostałego majątku, rzuci na niego klątwę $w$ imieniu biskupa.

Statuty Nankera przyznają dziekanom jurysdykcję sądowa, ale $w$ sprawach mniejszej wagi. Sprawy ważniejsze, zwłaszcza małżeńskie i kryminalne, jako nastręczające wiele trudności

639 M. de Montbach, j. w., s. 9.

${ }_{640}$ Por. np. Fijałek J., Najstarsze statuty synodalne Krakowskie biskupa Nankera z 2 paźdz. 1320 r., s. V-VIII.

641 Syn. krakowski Nankera $z$ r. 1320, stat. 50. Fijałek J., j. w., s. 63 .

642 Zob. odn. 633.

643 Syn. krakowski Nankera $z$ r. 1320, stat. 41. Tamże, s. 52-53. 
przy rozsądzaniu wbrew jakimkolwiek miejscowym zwyczajom sa stanowczo wyjęte spod ich kompetencji i podlegają jedynie władzy archidiakonów, prepozytów i biskupów. Do tychże zwierzchników mają się dziekani uciekać, o ile napotkaliby jakie trudności przy wydawaniu wyroków w dziedzinie sobie właściwej. Sądzić mają nie w karczmach, lecz w domach obok kościolów, w porze rannej, w razie potrzeby korzystając z rady ludzi doświadezonych i wyrokując według norm kanonicznych, a nie prawa lez ${ }^{644}$.

Rozwój urzędu dziekańskiego sprawia, że stają się oni poborcami różnych dziesięcin. Oczywiście było to możliwe i konieczne tam, gdzie istniały archidiakonaty dość rozlegỉe. Zebraną $w$ dekanacie dziesięcinę, jak to się zdarzyło np. w wypadku dziesięciny nałożonej przez Klemensa $\mathrm{V}$ i uiszczonej przez Polskę w r. 1327, przekazywali zwykle na ręce głównego poborcy ${ }^{645} \mathrm{co}$, rzecz zrozumiała, nie wykluczało pośrednictwa właściwego archidiakona ${ }^{646}$.

Ponieważ prawo stanowienia i przyzwalania na podatki państwowe należało do całego duchowieństwa, dziekani na synodach, gdzie takie sprawy załatwiano, stali się rzecznikami i pełnomocnikami podległego sobie kleru $w$ odniesieniu do danin nakładanych przez Państwo. Za ilustrację może służyć synod krakowski z r. 1462, uchwalający pomoc dla poszkodowanych mieszkańców ziemi Dobrzyńskiej. Obok archidiakonów występują tu dziekani, którzy w imieniu swoim i księży dekanalnych podejmuja odpowiednie decyzje ${ }^{647}$.

644 Syn. krakowski Nankera $z$ r. 1320, stat. 38. Fijałek J., j.w., s. $50-51$.

Spod władzy sądowniczej dziekańskiej sprawy małżeńskie wyjął w skali krajowej Mikołaj Trąba w swoim zbiorze z r. 1420, w rozdz. „De sponsalibus" (H e y z m a n n U., j. W., s. 235).

645 Por. np. Theiner A., dz. c., t. 1, s. 275-276.

646 Zob. odn. 353.

${ }_{647}$ U l a nowski B., Acta Capitulorum Cracoviensis et Plocensis. Odbitka z t. 6 Archiwum Kom. Hist. Kraków 1891, n. 82, 83, 85 i 89-95, s. $21-22$. 
Zyskując coraz więcej uprawnień kosztem swych bezpo-średnich przełożonych, jakimi byli archidiakoni, wchodzą oni w bliską styczność z właściwym rządcą diecezji, tjj. biskupem. Frzede wszystkim muszą bywać na synodzie diecezjalnym zwoływanym co rok, lub zależnie od potrzeby, jak to im nakazał synod wrocławski biskupa Konrada z r. $1446{ }^{648}$. W wypadku nieobecności grozi im kara trzech grzywien srebra, którą winni uiścić $w$ przeciagu miesiąca. $W$ przeciwnym razie mają wzbroniony wstęp do kościoła tak długo, jak długo będą zwlekać z uregulowaniem powyższej sumy.

Na synod udaja się wraz z całym duchowieństwem dekanalnym. Gdyby kto z kapłanów nie przybył, oni składają pisemny raport na ręce archidiakona. Ostatni przepis synod wrocławski z r. 1473 zmienil o tyle, że zezwolił, by dziekanowi towarzyszył tylko jeden ksiądz z dekanatu. Obaj udawali się na zjazd. kosztem pozostałych konfratrów. Na zebraniach synodalnych dziekani występowali $w$ stroju bardziej uroczystym $w$ porównaniu z niższym duchowieństwem i zajmowali miejsca tuż po kanonikach ${ }^{\mathbf{6 4 9}}$.

Uczestnictwo ich w obradach nie było bierne. Przeciwnie, znając z bezpośredniej obserwacji stan podległych sobie dekanatów, informowali biskupa o zauważonych niedomaganiach między duchowieństwem, a zwłaszeza o wypadkach konkubinatu, karciarstwa, lub opilstwa, i wykazywali zdrożności świeckich, przejawiające się $\mathrm{w}$ grabieży dóbr kościelnych, zaleganiu $z$ wypłatą dziesięcin, w napadach na księży, czy też w nagannym życiu, nie stroniącym od nieprawych małżeństw, cudzołóstwa, czarów, zabobonów czy lichwy. Zarazem podawali środki mogące przyczynić się skutecznie do usunięcia spostrzeżonych bolączek ${ }^{650}$.

Po skończonych obradach otrzymywali odpis powziętych uchwał, który, zgodnie z postanowieniem synodu wrocławskie-

648 M̈. de Montba ch, j. W., s. $58 \rightarrow 59$.

649 Syn. wroctawski biskupa Rudolfa $z$ r. 1473. Tamże, s. 87-88.

650 Syn. wrockawski biskupa Konrada $z r$. 1446. Tamże, s. 60. Por. także Syn. wrocławski biskupa Rudolfa zr. 1473. Tamże, s. 89 i 91; oraz syn. wrocławski tegoż biskupa Rudolfa z r. 1475. Tamże, s. 98-99. 
go odprowionego przez biskupa Tomasza w r. 1290, powinien być umieszczony na widocznym miejscu w każdym kościele parafialnym ${ }^{651}$. Kopię statutów synodalnych otrzymywał dziekan zwykle w ciągu miesiąca po zakończeniu zjazdu za pośrednictwem swego archidiakona. To nie przeszkadzało, że niekiedy sam ją podejmował z Kurii i przesyłał konfratrom ${ }^{652}$.

Poza tym do niego należało komunikować podwładnemu duchowieństwu wszelkie zarządzenia władzy diecezjalnej za pośrednictwem kurendy, przy czym winien odnotowywać kiedy zostały wykonane. Pisma jego urzędowe powinny być opatrzone specjalną pieczęcią dziekańską ${ }^{6 \breve{3}}$.

Szczególnie obszerne były jego uprawnienia $w$ dziedzinie pieczy nad obyczajami podległego sobie kleru. Arcybiskup Jakub Swinka, jak już wiemy ${ }^{654}$, zobowiązał na synodzie prowincjonalnym łęczyckim w r. 1285 dziekanów na równi $z$ archidiakonami, by o wykroczeniach osób duchownych donosili swemu biskupowi, który nie omieszka ich należycie ukarać. Według synodu wrocławskiego z r. 1473, dziekan uprzednio dołoży wszelkich starań, aby błądzącego naprawić ${ }^{655}$, owszem, W razie potrzeby ukaże go suspensą, lub postąpi $z$ nim tak, jak to uzna za stosowne ${ }^{656}$.

Do niego należało również przypilnować, aby kapłani spelniali należycie swoje obowiązki duszpasterskie, jak o tym mówi wyraźnie synod wrocławski r. $1454{ }^{657}$. W szczególności dochodził, czy $\mathrm{w}$ odpowiedni sposób administrują sakrament pokuty św., do czego przecież była potrzebna znajomość wypadków zastrzeżonych biskupowi. Synod-wrocławski z r. 1475 wprost nakazał, by każdy dziekan rzecz tę zbadal przed Wiel-

651 M. de Montbach, j. W., s. 4.

652 Zob. Syn. wroclawski Henryka $z$ Wierzbna $z$ r. 1305 i Syn. krakowski Nankera $z$ r. 1320 (przyt. w odn. 753 i 755), jak również Syn. wrocławski biskupa Konrada $z$ r. 1446. M. de Montbach, j. w., s.57.

${ }_{653}$ Syn. wroclawski biskupa Wactawa $z$ r. 1410, stat. 7. Tamże, s. 13.

654 Zob. odn. 631.

655 M. de Montbach, j. w., s. 94.

${ }_{656}$ Por. Syn. wroctawski biskupa Rudolfa $z$ r. 1473 (przyt. w odn. 650).

657 M. de Montbach, j. w., s. 77-78. 
kim Postem i zabronił spowiadać tym duchownym, którzy nie wykazali dostatecznej znajomości wspomnianych rezerwatów ${ }^{658}$.

W trosce o należytą piecze nad duszami dopiero co wspomniany synod wroclawski biskupa Piotra z r. 1454 polecil dziekanom wezwać wszystkich księży zatrudnionych w duszpasterstwie, zwlaszcza zaś proboszczów, i dowiedzieć się od nich, czy posiadają święcenia kapłańskie i czy stanowiska swoje zajmują zgodnie z prawem. W wypadku wykrytych nadużyć mają winnych przytrzymać, i to $\mathrm{w}$ razie potrzeby nawet $\mathrm{z}$ pomoci. władzy świeckiej, i odesłać do Ordynariusza, a ten ich odpowiednio ukaże dla zbawiennego przykładu innych ${ }^{659}$.

Zarazem obowiązkiem dziekanów było czuwać nad całością mienia kościelnego i nie dopuszczać do jego umniejszania przez przywłaszczanie, darowizny, lub sprzedaż. W myśl zarządzenia wymienionego przed chwilą synodu wrocławskiego z r. 1454 każdy beneficjat $\mathrm{w}$ ciągu dwu miesięcy od zakończenia synodu winien swemu dziekanowi przesłać dwa wykazy dla doręczenia ich władzy diecezjalnej. W pierwszym z nich należało uwidocznić cały majątek kościelny ruchomy i nieruchomy, wszystkie dochody i uprawnienia oraz spis takich rzeczy kościelnych, jak kielichy, księgi, aparaty liturgiczne i inne kosztowności. Drugi egzemplarz powinien obejmować odpis wszelkich dokumentów świadczących o fundacjach, erekcjach czy przywilejach beneficjalnych ${ }^{660}$.

Tym bardziej dziekani mieli obowiązek zwrócić uwagę na zabezpieczenie majątku kościelnego $\mathrm{w}$ razie śmierci którego z kapłanów ze swego dekanatu, o czym wyżej była mowa ${ }^{67}$. Choć synod wrocławski biskupa Rudolfa z r. 1473 nakazywal im zdawać ścisły rachunek $\mathrm{z}$ administracji osieroconego $\mathrm{w}$ ten sposób beneficjum i odsyłać nadwyżkę dochodów do kasy bi-

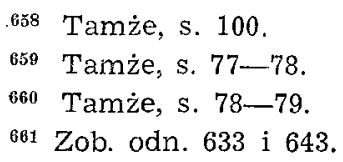


skupiej ${ }^{662}$, na ogół jak to widać ze statutów Mikołaja Trąby ${ }^{663}$, zarządzenia wcześniejszych synodów, zezwalające dziekanom na większą swobode w rozporządzaniu nowymi dochodami, utrzymały się w mocy.

Jednym z trudniejszych obowiązków dziekańskich to wizytacja parafii. Mówi o niej wyraźnie synod kaliski arcybiskupa Jaroslawa z r. $1357^{664}$ i to $w$ ten sposób, jakby nie była czymś nowym, ale oddawna znanym ${ }^{\tilde{6} 65}$. Jej wzorem była wizytacja odbywana przez archidiakona, oczywiście z pewnymi zmianami, w szczególności z zakresu ceremoniału zewnętrznego, który wykazywał o wiele mniej wystawności i splendoru ${ }^{666}$. Nadto dziekan występował z mniejszym od niego autorytetem. Po wykryciu $\mathrm{w}$ czasie wizytacji jakiego nadużycia donosił o rim archidiakonowi, ten zaś sprawę przedstawiał biskupowi, lub jego zastępcy. ${ }^{668}$ To nie przeszkadzało, że w podobnych wypadkach mógł sam bezpośrednio zwracać się do Kurii ${ }^{668}$. Więcej, niejednokrotnie on karał winnych $\mathrm{w}$ imieniu ordynariusza ${ }^{679}$ choć zasadniczo nasze prawodawstwo nie zezwalało, by mógł spełniać czynności sądownicze, przysługujące dość długo

${ }_{662}$ M. de Montbach, j. w., s. 95.

${ }_{663}$ Fijalek-Vetulani, dz. c., s. 57.

664 Stat. 7 tegoż synodu. H u be R., j. w., s. 211.

${ }_{665}$ Por. odn. 636.

666 Zob. odn. 328. Warto zwrócić uwage, że IMikołaj Trąba w swoim zbiorze praw z r. 1420, w art. „De officio archidiaconi”, cyt. w odn. 315 i 636 a obejmującym ważniejsze cele wizytacji archidiakońskiej, te same uprawnienia przypisuje zastępcom archidiakonów, czyli dziekanom.

${ }^{607}$ Por. Syn. łęczycki Jakuba Swinki z r. 1285, stat. 40 (przyt. w odn. 6ํำ.

${ }_{668}$ Por. np. odn. 630.

${ }_{669}$ Por. np. odn. 643 przytaczający stat. 41 synodu krakowskiego Nankera z r. 1320 w sprawie majątku kościelnego po śmierci beneficjata; odn. 656 i 650 , gdzie cytowany jest syn. wrocławski $z$ r. 1473. zezwalający dziekanom wszelkimi karami ścigać przestępstwa duchownych; oraz syn. diecezjalny gnieźnieński z r. 1456 , stat. 15 . Ul a n o w. ski B., Acta Capitulorum nec non Iudiciorum ecclesiasticorum, t. 1; n. 1860, s. 423. 
archidiakonom ${ }^{670}$. W ten sposób wizytacja okazywała się bardziej owocna $\mathrm{w}$ porównaniu $\mathrm{z}$ archidiakońską, bo, obejmując swoim zasięgiem mniejszą ilość parafii, i częściej i dokładniej bywała przeprowadzana.

Wreszcie na jego barkach spoczywał obowiązek zwoływania co pewien czas zebrań podległego sobie duchowieństwa czyli kongregacji dekanalnej.

Synod diecezjalny gnieźnieński z r. 1456 poleca, aby dziekan po odbyciu synodu na umyślnym zjeździe zapoznał księży, W szczególności zaś proboszczów, z treścią ogłoszonych na nim statutów i dopilnował, by je sobie przepisali ${ }^{671}$.

Bardzo treściwie i zarazem wyczerpująco zadania i organizację zebrań dekanalnych skreślił w swych statutach diecezjalnych biskup wrocławski Jan V z r. 1509, który w ten sposób pisze 672: „Ponieważ znaleźliśmy w naszej diecezji wielu kapłanów i duchownych, którzy wskutek niedbalstwa nawet nie czytają statutów, chociaż je posiadają, aby więc i takich pociągnąć i niejako zniewolić do zapoznania się z nimi, chcemy i nakazujemy, iżby każdy bez wyjątku dziekan na terenie swojego okręgu, w miejscu odpowiednim, bądź w mieście, bądź na wsi, co kwartał zbierał $w$ suche dni wszystkich kapłanów i rządców kościoiów. Duchownych tych niniejszą ustawą synodalną zobowiązujemy do udziału w powyższych zjazdach z wyjątkiem kilku, którzy pozostaną w domu dla obsługi duchowej wiernych pozbawionych chwilowo swych pasterzy. Na drugi raz powinni być wyznaczeni do pozostania w domu inni kapłani, aby w ten sposób każdy z nich mógł wziąć udział w dekanalnej konferencji. Dziekanom zaś surowo nakazujemy i pod świętym posłuszeństwem ich zobowiązujemy, żeby na kongregacjach owych przede wszystkim statuty naszych poprzedników oraz nasze własne wszystkim zebranym kapłanom nakazali odczytać wyraźnie, porządnie i w całości, a to

${ }^{670}$ Por. odn. 638 lub 644.

671 Syn. diecezjalny gnieźnieński $z r$. 1456, stat. 15. U I a n o w s k i B., j. W., n. 1860, s. 423.

672 M. de Montbach, j. w., s. 115-116. 
w tym celu, aby nikt nie mógł się zasłaniać ich nieznajomością, lecz przeciwnie, by je lepiej i chwalebniej ku czci bożej pełnił.

Potem każdy dziekan, stosownie do przepisów jakie wydali nasi poprzednicy, wiernie i pilnie wypyta, zbada i dochodzić będzie, czy wszyscy dekanalni księża, zwłaszcza przybyli z obcych diecezji, posiadają święcenia kapłańskie oraz gdzie i kiedy je przyjęli, na jakiej podstawie każdy z nich sprawuje rządy w parafii, czy na mocy instytucji kanonicznej, czy tylko komendy; następnie - jak żyje, jak się prowadzi, i czy w czym tu nie wykroczył.

Przy tym zabraniamy, by ktokolwiek zebranie opuszczał, lub przed wyczerpaniem całego porządku dziennego wyjeżdżał z miasta, albo ze wsi, gdzie zjazd się odbywa. Nakazujemy również, aby dziekan nikomu nie zezwalał na wcześniejszy powrót do domu i to pod karą klątwy oraz pieniężną, którą sami wyznaczymy, chyba, że záchodziłaby słuszna ku temu potrzeba".

Jest rzeczą znamienną, iž późniejsze synody do skreślonego tu obrazu kongregacji dekanalnej ten czy inny rys mniej lub więcej znamienny dorzuca, lecz zasadniczego jej charakteru nie zmienią.

Na zakończenie przeglądu praw i obowiązków dziekana, tyczących się podległego mu duchowieństwa, trudno nie wspomnieć o jego uprawnieniach $\mathrm{w}$ odniesieniu do aspirantów do stanu duchownego. Mianowicie synod prowincjonalny piotrkowski z r. $1510^{673}$ i $1511^{674}$ postanowił, aby przystępujący nawet do niższych święceń przedstawiali władzy diecezjalnej świadectwo o obyczajach i przydatności wystawione przez dziekana tego okręgu, w którym zamieszkiwali. Oczywiście

673 Syn. prowincjonalny piotrkowski $z$ r. 1510, stat. 9. Ula now$\mathrm{ski}$ B., $M$ ateriaty, s. 348 .

${ }^{674}$ Syn. prowincjonalny piotrkowski $z$ r. 1511, stat. 2. Ulanow$\mathrm{ski}$ B., Acta Capitulorum nec non Iudiciorum ecclesiasticorum, t. 1; s. 351. Statut ten pokrywa się prawie całkowicie $\mathrm{z}$ poprzednim, choć wprowadza pewną zmianę, pisze bowiem: ,...litteras testimoniales decani ruralis et unius aut duorum plebanorum vicinorum eiusdem decanam tus, ubi degit"... 
dzielkan takie pismo sporządzał na podstawie opinii, jaką zainteresowanemu wystawiał jego proboszcz.

$\mathrm{Na}$ koniec nie można pominąc sprawy stanowiska dziekana $\mathrm{w}$ odniesieniu do wiernych $\mathrm{z}$ podległego mu okręgu. Jest ono caikowicie pasterskie. Ma on pilnie baczyć na ich życie i z pomocą kilku ludzi, zazwyczaj dobranych spośród osób świeckich, wykrywać pojawiające się wykroczenia na tle obyczajowym, lub też godzące w czystość wiary; ujawnione nadużycia tępić, w najgorszym zaś razie donosić o nich biskupowi. Mówi o tym wyraźnie synod wrocławski z r. 1475, który tak stanowi ${ }^{675}$ : ,W każdym dekanacie dziekan wspólnie z seniorami ma wybrać i na wzór świadków synodalnych ustanowić kilku cnotliwych i bogobojnych ludzi ze stanu duchownego lub świeckiego, którzy by razem z nim, czy też samodzielnie zwracali troskliwă uwagę na publiczne występki ludu, w szczególności na żyjących $\mathrm{w}$ nieprawych związkach malżeńskich, cudzołożników, wróżbiarzy, na duchownych prowadzących karczmy lub do nich uczęszczających, na lichwiarzy, na tych, którzy prześladują duchowieństwo, przywłaszczają sobie dobra kościelne za życia, albo po śmierci księdza, oraz na inne podobne nadużycia. O wszystkim, co zdrożnego zauważą, doniosą oni dziekanowi, a ten biskupowi przy okazji odprawiania synodu diecezjalnego".

Nakreślony tu obraz praw i obowiązków dziekańskich bezsprzecznie nie wyczerpuje całokształtu zagadnienia. Nie należy bowiem zapommać, że synody polskie o instytucji dziekańskiej w pierwszym okresie jej istnienia mówią raczej przypadkowo, główną uwagę przywiązując do archidiakonów. Ci, jako bardziej wykształceni, więcej się okazywali zdolni do niesienia pomocy swemu biskupowi przy sprawowaniu przezeń rządów diecezji, co nie mogło nie odbić się we współczesnym prawodawstwie ${ }^{678}$.

Niemniej jednak przytoczone zarządzenia naszych synodów świadczą, że stanowisko dziekanów, przynajmniej teoretycznie,

675 Zob. Syn. wrockawski biskupa Rudolfa $z$ r. 1475 (przyt. w odn. 650!.

676 C̈hodyński Z., Dziekan wiejski. Encyk1. Kość. Nowodworskiego, t. 4 , s. 454 . 
było bardzo wysokie. Przeciez, jak to niemal $z$ emfazą wyraża się arcybiskup Jarosław na synodzie prowincjonalnym kaliskim z r. $1357^{677}$, a za nim Mikołaj Trąba na takimże synodzie z r. $1420^{678}$, dziekan to zastępca archidiakona, a więc posiadający te same co $\mathrm{i}$ on uprawnienia, oczywiście $w$ zależności od niego i ograniczone do terenu dekanatu ${ }^{679}$. Niższe jego przygotowanie naukowe sprawiło, że nie zajął on właściwego miejsca $w$ życiu i prawodawstwie kościelnym Polski Piastów i Jagiellonów. Co gorsza, w niektórych diecezjach w w. XVI zupełnie o nim zapomniano ${ }^{680}$.

\section{B. Upadek i odrodzenie instytucji dziekanatu}

Koniec XV i początek XVI w. przynosi upadek znaczenia urzędu dziekańskiego, a nawet tu i ówdzie jego zanik.

Można pominąć milczeniem fakt, że statuty synodalne przemyskie z r. 1511, 1519, 1525, i 1529 nic nie mówią a dziekanach ${ }^{681}$.

Prawdopodobnie w diecezji tej nie byli oni wówczas znani, choć już istniały tam i działały konfraternie kleru powiatowego, jak np. z r. 1450 z ziemi łańcuckiej i z r. 1460 w ziemi sanockiej, odbywające zjazdy pod przewodnictwem wybranych proboszczów, do złudzenia przypominające kongregacje dekanalne ${ }^{682}$.

Natomiast zastanowić musi, że, o ile w r. 1327 bezpośrednimi poborcami świętopietrza byli prawie z zasady dziekani ${ }^{683}$,

677 Zob. odn. 636.

678 Zob. odn. 666 oraz 315 i 636.

679 Chodyński Z, Dziekan wiejski. Encykl. Kość. Nowodworskiego, t. 4 , s. 454 i 457 .

680 Tamże, s. 457.

681 Por. Ulanowski B., Analecta ad historiam iuris canonici in dioecesi Premisliensi. Archiwum Kom. Histor., t. 5, s. 378-392.

682 Tamże, s. 430-436.

${ }^{883}$ Zob. wyżej odn. 645 i 646. 
o tyle w r. 1476-1484 w wykazach z dokonywanej zbiórki na cgół nie ma o nich mowy, mimo, że dekanaty nadal stanowiły jednostki administracyjno-skarbowe ${ }^{684}$.

Konstytucje synodalne warmińskie biskupa Eukasza $z \mathrm{r}$. 1497, dość obszerne i wydane dla diecezji, gdzie urząd dziekański niewątpliwie był znany, zaledwie we wstępie o nim wspominają, nic natomiast nie mówią na dalszych kartach o treści jego obowiązków ${ }^{685}$. Tymczasem w ustawach synodalnych kardynała Hozjusza z r. 1565, a więc po dokonaniu szczęśliwych zmian w życiu polskiego Kościoła, o instytucji dziekanatu pisze się b. wiele, jako o organie władzy biskupiej, choć, rzecz zrozumiała, bezpośrednio podległym archidiakonowi ${ }^{686}$.

Całkowicie wyraźnie rysuje się upadek znaczenia dziekana na terenie diecezji włocławskiej i plockiej. Dowodem tego jest ordynacja archidiakona płockiego i włocławskiego Pawła Sulisławicza z Liczek z r. 1487 dla duchowieństwa dekanatów Brześcia, Raciążka i Bydgoszczy ${ }^{687}$. Aczkolwiek już dość dawno, bo przeszło przed wiekiem, było przyjęte, że dziekan jako pelnomocnik i zastępca archiđiakona często go wyręcza w przecrowadzaniu wizytacji kościołów parafialnych ${ }^{688}$, pośredniczy w przesyłaniu pism władzy duchownej ${ }^{689}$, i pilnie baczy na postępowanie podległych sobie kapłanów ${ }^{690}$, archidiakon Paweł zaraz na wstępie powiada o sobie $\mathrm{z}$ naciskiem, iż jest "okiem biskupa", do niego należy corocznie wizytowanie parafii $i$ on również zdaje sprawozdanie ordynariuszowi o życiu i obyczajach duchowieństwa. Powiadamiając kler o zamierzonej wizytacji, poleca bezpośrednio proboszczom przesyłać swój okólnik drogą okrężną - „vicinus ad vicinum”. Gdy pominiemy krótką wzmianke $w$ adresie pisma, gdzie wymieniono je-

${ }_{684}$ Theiner A., dz. c., t. 2, s. 183 nn.

085 Constitutiones Synodales Dioecesis Varmiensis, s. 7-28.

686 Tamże, s. 38. Por. także, s. 39, 54 i 72.

687 Chodyński Z., Statuta Synodalia Dioecesis Wladislaviensis et Pomeraniae, s. 22-27.

688 Por. odn. 664.

${ }^{689}$ Por. odn. 654.

600 Por. odn. 655 . 
dynie nazwy dekanatów, w całej ordynacji o urzędzie dziekana nie znajdziemy ani słowa. Dojdzie nawet do tego, że jak to było na początku rządów biskupa Rozdrażewskiego (r. 15921600) ${ }^{691}$, archidiakonat włocławski liczyć będzie już nie trzy, lecz tylko dwa dekanaty ${ }^{692}$.

Podobne stosunki zapanowały $w$ diecezji płockiej. Ponieważ wskutek działań wojennych wiele kościołów w Ziemi Dobrzyńskiej uległo zniszczeniu i osieroceniu, biskup Wincenty po zwołaniu zainteresowanych kapłanów i patronów oraz po naradzie $z$ nimi dokonal $w$ roku 1502 nowego rozgraniczenia parafii, łącząc $z$ sobą zbyt spustoszone, lub też wskrzeszając je po zapewnieniu im odpowiedniego zaopatrzenia przez miejscovvego kolatora ${ }^{693}$. Gruntowną reorganizację terytorialną całej diecezji przeprowadził na synodzie płockim biskup Erazm W r. $1506^{704}$. Jest znamienne, że $w$ obu wypadkach nawet wzmianki nie uczyniono o urzędzie dziekana lub o jego obowiązkach, choć przecież na początku XV w. był on tu instytucją ważką i żywotną ${ }^{695}$.

Uwagi powyższe aż nadto jasno stwierdzają, iż omawiany okres $\mathrm{w}$ niektórych diecezjach Polski, to okres upadku instytucji dziekańskiej.

Jakie były przyczyny tego zjawiska? Oczywiście - różnorakie. Jedne $z$ nich miały charakter bardziej lokalny i przejściowy. Inne, tkwiące korzeniami w wewnętrznym życiu Kościoła, ujawniały się na terytorium bez porównania większym i były trudniejsze do usunięcia.

691 Encykl. Kość. Nowodworskiego, t. 23, s. 514-524, sv. Rozdrażewski Hieronim.

${ }^{692}$ Chodyński Z., Statuta Synodalia Dioecesis Wladislaviensis et Pomeraniae, s. IX.

693 Acta iudicii eclesiastici plocensis. U 1 a nowski B., Acta Capitulorum nen non Iudiciorum ecclesiasticorum selecta, t. $3, \mathrm{cz} .1$, n. 206 , s. $84-86$.

694 Tamże, n. 300 , s. 141.

695 Por. np. Z a chorows ki S., Jakub biskup plocki $i$ jego dzialalność ustawodawcza i organizacyjna 1396-1425. Kraków 1915. A.U., s. 18 i cytowany tamże statut biskupa Jakuba z jego postanowień synodalnych $\mathrm{z}$ r. 1423. 
Do pierwszej kategorii należy zaliczyć wojny pograniczne, które, jak to już wiemy z dziejów. Ziemi Dobrzyńskiej ${ }^{696}$ dewastowały parafie, obracały $w$ ruinę domy boże, a przez to zubożały życie kościelne.

Do kategorii drugiej włączyć trzeba walki religijne, rozgorzałe u nas na wstępie XVI w. i w pewnych stronach Rzeczypospolitej dochodzące do szczególnego nasilenia oraz powodujące wyjątkowe spustoszenia, czego dowodem $\mathrm{m}$. in. wspomniany wyżej stan diecezji włocławskiej $w$ zaraniu rządów biskupa Rozdrażewskiego ${ }^{697}$.

U podstawy tych walk i całej rewolucji religijnej, by pominąc inne powody ${ }^{698}$, leży przede wszystkim zaniedbanie się w obowiązkach samych biskupów. Posiadając zbyt rozległe diecezje, zajęci sprawami politycznymi, ulegając przy tym powszechnej chorobie XVI w., chciwości, nie mieli ani czasu, ani chęci do zajmowania się sprawami kościelnymi.

Korzystali więc z ogólnie przyjętego zwyczaju dzielenia diecezji na kilka archidiakonatów i obowiązki swoje przelewali na archidiakonów ${ }^{699}$ oraz ich pomocników, dziekanów wiejskich. Co gorsza, w wyborze tak pierwszych, jak i drugich kierowali się często nie rozumnie pojętym dobrem Kościoła, lecz własnym interesem materialnym, za co słusznie ich obwinia kapituła krakowska w swej instrukcji dla posłów na synod prowicjonalny zwołany na dzień 6 listopada $1554 \mathrm{r} .{ }^{700}$.

696 Zob. odn. 693 (一) i zam. n. 206, s. 84.

${ }^{607}$ Por. odn. 805 i tamże w szczególności s. 517, oraz K r y n icki W., dz. c., t. 2, s. $431 \mathrm{nn}$.

${ }^{698}$ Mówi o nich dość obszernie K r y n i c k i W., dz. c., t. 2, s. 428-431.

${ }^{699}$ Właśnie synody polskie z XVI wieku tak często mówią o archidiakonach, np. syn. prowincjonalny piotrkowski $z$ r. 1510 , stat. 4 (Ul a towski B., Materiaty, s. 348); Syn. prowincjonalny piotrkowski $z$ r. 1511, stat. 3 (tamże s. 351); Syn. diecezjalny gnieźnieński z r. 1512, statt. 67 (tamże, s. 362); Syn. prowincjonalny tęczycki $z r .1527$, stat. 10 (tamże, s. 369-370); Syn. prowincjonalny piotrkowski $z$ r. 1542, stat. 4 i 14 (tamże, s. $389-390$ i 393 ).

700 Cała ta instrukcja, podana przez Ulanowskiego B. W jego Materiatach, s. 417-427, jest jednym wielkim oskarżeniem ówczesnego episkopatu. 
Rzecz jasna, że w takich warunkach życie kościelne musiało ulec dezorganizacji i zwyrodnieniu. W szczególności dziekani pochodzący spośród niższego duchowieństwa, częstokroć zaniedbanego pod względem umysłowym i moralnym, coraz mniej okazywali się zdolni do pełnienia swoich obowiązków, a przez to coraz mniej potrzebni. Nic przeto dziwnego, iż powoli tracą na znaczeniu i gdzieniegdzie nawet całkowicie znikają.

Opisany stan rzeczy stanowczo domagał się jak najszybszej odmiany. Przywrócenie dziekanom ich dawnego stanowiska w życiu organizacyjnym diecezji, więcej, wzmocnienie tej pozycji, by nie powiedzieć - jej wskrzeszenie, było wprost nakazem chwili, jeśli postępy nowinek protestanckich miały ulec zahamowaniu, a Kościół - odrodzeniu.

Impuls do zbawiennych reform wyszedl od kapituły płockiej. Oto na posiedzeniu adbytym w dniu 4 maja $1551 \mathrm{r}$. postanawia ona, aby zgodnie $z$ dawnym powszechnym zwyczajem $w$ każdym dekanacie zostały ustanowieni dziekani, którzy by co rok zwoływali na kongregację dekanalne uzależnione od siebie duchowieństwo, dopilnowywali stosowania się przez nie do obowiązujących przepisów prawa kanonicznego i wykraczających donosili biskupowi, co wszystko razem wpłynęłoby na wytępienie nadużyć i przeprowadzenie tak upragnionej reformy ${ }^{701}$.

Jak sprawa ta była ważna i jak aktualnym stawało się $\mathrm{w}$ drugiej połowie XVI w. zagadnienie przywrócenia urzędu dziekańskiego, świadczy inna uchwała kapituły płockiej z 9 września tegoż 1551 roku. Oto, powołując się na niedawno powziętą ustawę i uprzednie prośby oraz przypominając odnośne przepisy synodalne, po raz wtóry usilnie błaga biskupa o ustanowienie dziekanów na terenie całej diecezji ${ }^{702}$.

Jak juź wiemy, w zbożnych poczynaniach przyszła w pomoc kapitule płockiej w trzy lata później kapituła krakowska, któ-

701 U lanowski B., Acta Capituli Plocensis ab an. 1514 ad an. 1577. Odbitka z. t. 10 Archiwum Kom. Histor. Kraków 1915, n. 202, s. 211.

702 Tamże, n. 209, s. 215. 
ra dała tak znamienną instrukcję swym posłom, udajøeym sie na synod prowincjonalny ogłoszony na dzień 6 listopada $1654 \mathrm{r}$.

Rozbudzony duch reformy odtąd już nie spocząı, aż doprowadził do upragnionego celu. Fakt ten ogromnej wagi dla życia Kościoła w naszej Ojczyźnie dokonal się podczas obrad synodu prowincjonalnego, zwołanego na dzień 4 marca $1561 \mathrm{r}$. do Warszawy przez prymasa Jana Przerębskiego. Dla ożywienia pracy duszpasterskiej wśród duchowieństwa i postawienia skutecznej zapory krzewiącej się pseudoreformacji zdecydowano wskrzesić urząd dziekański tam, gdzie poszedł w zapom» nienie, tam zaś, gdzie istniał, ożywić przez tworzenie $w$ miare potrzeby nowych dekanatów. Zarazem przypomniano jakie są główniejsze dziekańskie obowiązki. W tym względzie synod poszedł po linii dezyderatów kapituły płockiej, a nawet je uzupełnił przez nakaz, by dziekani kongregacje swoje odbywali dwukrotnie do roku ${ }^{703}$.

Jest rzeczą zrozumiałą, że nie od razu i nie wszędzie uchwały synodu prowincjonalnego warszawskiego znalazły właściwy posłuch. Sprawa przywrócenia dekanatów będzie zajmować umysły podczas obrad synodu prowincjonalnego gnieźnieńskiego za arcybiskupa Stanisława Karnkowskiego w r. 1583, kiedy to zostali surowo napomnieni archidiakoni, aby dekanaty wiejskie wznowili i dziekanów pouczyli o ciążących na nich obowiązkach ${ }^{704}$.

Niemniej jednak palące zagadnienie szcześliwie ruszyło $z$ martwego punktu. Odtąd już nie będzie synodu, który by o nim w sposób mniej lub więcej wyczerpujący nie mówił ${ }^{705}$. Znalazło się ono na poczesnym miejscu $w$ dwu klasycznych pracach z początku XVII w.: w „Epistola Pastoralis" kardynała Maciejowskiego i w „Reformationes Generales” biskupa krakowskiego Szyszkowskiego. Dzięki zmienionym warunkom powoli dojdzie do tego, że dziekani usuną w cień swoich bez-"

703 Żbiór Wężyka z r. 1761 , s. 56-57.

704 Zob. ođ̉n. 325.

${ }^{705}$ Chodyński Z., Dziekan wiejski. Encykl. Kość. Nowodworskiego, t. 4 , s. 457 . 
pośrednich zwierzchników, archidiakonów, przejmując ich uprawnienia i zostawiając im samą tylko godność i honorowe miejsce $\mathrm{w}$ stallach ${ }^{\tau 06}$.

\section{Zakończenie}

Bogata i ciekawa historia instytucji dziekanatu świadczy, iz jest to urząd zgoła starożytny i ogromnie doniosły. Charakterem swoim, wynikającym $z$ treści przysługujących mu uprawnień i ciążących na nim obowiązków, odpowiednio zmodyfikowanych zależnie od epoki rozwoju Kościoła, sięga dziejów pierwotnego chrześcijaństwa.

$\mathrm{Za}$ protoplastów posiada biskupów wiejskich czyli chorepiskopów oraz dostojników, którzy ich z biegiem lat pod wpływem zmieniających się warunków życia zastąpili, tj. wizytatorów, archidiakonów i archiprezbiterów, będących zasadniczo ostatnim stadium ewolucji dziekanatu.

Żywa świadomość tej prawdy istniala jeszcze w XVIII w., czego świadectwem może być $m$. in. nasz syn. chełmski z 1717 r., z pewną emfazą się wyrażający: „Niech pomną Przewielebni Księża Dziekani, że wspólny Biskupom i Archidiakonom urząd sprawują" 707.

Nie zniknęła ona i we współczesnym kościelnym prawodawstwie. Przecież Kodeks Prawa Kanonicznego na określenie dziekanów używa nie innej nazwy, jak tej, którą nadał stworzonym umyślnie przez siebie urzędnikom diecezjalnym św. Karol Boromeusz w 1565 r., a mianowicie ,vicarii foranei”, którzy mie-

706 Chodyński Z., j. w., s. 457.

707 Synodus Dioecesana Chelmensis ab... O. Cristophoro Joanne in Słupow Szembek... Epo Chelmensi, Nominato Premisliensi, Praeposito Generali Miechoviensi, Crasnostaviae, in Esia Cathedrali Prasente Universo Diaecesis Clero Celebrata Die 18 Mensis Julii, et aliis duabus sequentibus diebus, A. D. 1717. Zamoscii, Typis Universitatis, c. 3 n. 1:

„Noverint DD. Decani se commune Episcoporum et Archidiaconorum Officium exercere". 
ii być początkowo zastępcami Ordynariusza poza miastem bi-skupim, a którzy z czasem $w$ ogóle stali się pośrednim organem między naczelną władzą diecezjalną i podległym jej ducho-wieństwem.

Co do samego terminu „dziekan”, najczęściej spotykanego $\mathrm{w}$ mowie potocznej i ustawach synodalnych na oznaczenie owego zastępcy biskupa, wyraz ten ma również swoją poważną przeszłość. O ile na terenie Francji i to w formie ,decania" został po raz pierwszy użyty w postanowieniach synodu odbytego w Tuluzie w 844 r., czyli na początku epoki Karolingów, kiedy z urządzeń klasztornych zaczął przedostawać się do organizacji duchowieństwia diecezjalnego, to $u$ nas ze słowem „dziekan" spotykamy się pierwszy raz nie na synodzie Łączyckim w r. 1285 arcybiskupa Jakuba Świnki, co podtrzymywał Zenon Chodyński, a za nim prof. Abraham i Jan Fijałek, lecz $\mathrm{w}$ statutach synodu prowincjonalnego, odprawionego w $1248 \mathrm{r}$. we Wrocławiu przez archidiakona leodyjskiego Jakuba, późniejszego papieża Urbana IV.

Niewątpliwie, ewolucja urzędu dziekańskiego sprawiła, że w świetle współczesnego nam prawodawstwa dziekan jest W gruncie rzeczy dalekim echem swoich wielkich poprzedników, po których dziedziczy jedynie pewne stanowisko honorowe i uprawnienia inspekcyjno-opiekuncze $w$ granicach swego dekanatu. Pozycja ta jest jednak wysoka i przez Kodeks Prawa Kanonicznego została silnie podkreślona jako s z c z e.gólny urzą pomocniczy Biskupa. Jeśli tylko zgodnie $z$ wymogami prawa urząd ten będzie powierzany osobom kompetentnym, tj. proboszczom gorliwym, prawym, światłym i roztropnym, Ordynariusz znajdzie w nim najwłaściwszy środek do sprężystego kierowania duchowieństwem i do potęgowania życia religijnego wśród wiernych, co przecież już znalazło tak dobitny wyraz w dziejach Kościoła w Polsce przedrozbiorowej.

Ponieważ rozwój prawa kanonicznego idzie w kierunku wzmocnienia władzy biskupiej w ramach ogólnej organizacji Kościoła, należy mieć nadzieję, że i urząd dziekański w dalszej historii nabierze nowego znaczenia i blasku. 


\title{
WYKAZ ŻRÓDEF, I OPRACOWAN
}

\author{
I. ŹRÓDEA
}

A.

1. Abraham W., Statuta legata Gentilisa wydane dla Polski na synodzie w Preszburgu 10 listopada r. 1309. Odbitka z t. 5 Archiwum. Komisji Prawniczej Akad. Umiej. Kraków 1893.

2. Antiquissimae constitutiones synodales provinciae gnesnensis maxima ex parte nunc primum e codicibus manu scriptis typis mandatae. Editionem curavit Romualdus Hube. Petropoli anno 1856.

C.

3. Codex Diplomaticus Poloniae ... Editus studio et opera Leonis Rzyszczewski et Antoni Muczkowski ... Varsaviae Typis Stanislai Strębski, 1847-1848, t. 1-2.

4. Codex Iuris Canonici. Typis polyglottis vaticanis 1943.

5. Codicis Iuris Canonici Fontes cura Emi Petri Card. Gasparii editi. Vol. 1. Romae 1947. Vol. 7, Romae 1935.

6. Concilii Tridentini canones et decreta. Wyd. A. Bisping. Monasterii Guestphalorum 1845.

7. Congregatio synodalis totius provinciae gnesnensis ab archiepiscopo Jacobo Uchański coacta... Petricoviae die 1 Octobris 1578 anni celebrata nec non congregatio synodalis archidiaconatus camenecensis ab archiepiscopo Laurentio Gembicki in oppido Camen die 26 Septembris 1619 anni celebrata nunc primum ... dr Alexander Kakowski ... edidit.. Petropoli 1913.

8. Constitutiones Synodales Dioecesis Varmiensis. Brunsburgae Apud Georgium Schönfels Anno 1612.

9. Constitutiones Synodorum Metropolitanae Ecclesiae Gnesnensis Provincialium Authoritate Synodi Provincialis Gembicianae Per Deputatos recognitae Jussu vero et opera ... D. Joannis Wężyk ... Archiepiscopi Gnesnensis I. N. R. P. P. editae. Cracoviae In Typographia Collegii Majoris Univer: Cracovien: Reimpresse Anno Domini 1761. (Cyt. Zbiór Wężyka z r. 1761).

10. Constitutiones Synodorum, Metropolitanae Ecclesiae Gnesnensis, Provincialium, tam vetustorum quam recentiorum, usque ad Annum Domini, M.D.LXXVIII. (1578). Studio Et Opera... Domini Stanislai Karnkowski,... Episcopi Wladislaviensis et Pomeraniae, 
collectae ...et in unum volumen redactae. Cracoviae, Andreas Petricouius impressit. Anno Domini,1579. (Cyt. Zbiór Karnkowskiego z r. 1579).

11. Corpus Iuris Canonici. Editio Lipsiensis secunda... instruxit Aemilius Friedberg. Pars prior. Decretum Magistri Gratiani. Pars secunda. Decretalium Collectiones. Ex Officina Bernardi Tauchnitz. Lipsiae 1879-1881.

12. Corpus Iuris Civilis. Editio stereotypa ex Officina Caroli Tauchnitii cura D. Joannis Ludovici Guilielmi Beck... Vol. 2. Lipsią apus Carolum Cnobloch 1837.

13. Corpus scriptorum ecclesiasticorum latinorum editum consilio et impensis Academiae litterarum caesareae vindobonensis. Vindobonae 1868, t. 3 .

D.

14. Decretales Summorum Pontificum pro Regno Poloniae et Consti.tutiones Synodorum Provincialium et Dioecesanarum Regni ejusdem ad summam collectae... Curantibus plerisque sacerdotibus posnaniensibus editae. Tomus I... Edito innovata. Posnaniae. Sumptibus Iaroslai Leitgeber 1883.

15. Decretales Summorum Pontificum pro Regno Poloniae et Constitutiones Synodorum Provincialium et Dioecesanarum Regni ejusdem ad summam collectae... Editae cura et studio Zenonis Chodyński... et Eduardi Lirowski... Tomus II Posnaniae. Sumptibus et typis Iaroslai Leitgeber 1882.

16. Die Breslauer Diözesansynode vom Jahre 1446 vom Dr. theol. Franz Xaver Seppelt... Breslau 1912.

17. Długosz J., Liber beneficiorum, t. 2. Opera omnia cura Alexandri Przezdziecki edita, t. 8. Kraków 1864.

E.

18. Héfélé - Leclercq, Histoire des conciles, t. 1-2 i 4-5. Paris 1907-1913.

19. Hencel A. Z., Ustawođawstwo Kościola polskiego. Starodawne Prawa Polskiego Pomniki, t. 1, s. 331-428, Warszawa 1856.

K.

20. Kodeks Dyplomatyczny Katedry Krakowskiej S. Wacława... Wydał i przypisami objaśnił Dr. Franciszek Piekosiński. Kraków 187ł, t. 1 . 
21. Kodeks Dyplomatyczny Księstwa Mazowieckiego. Wyd. T. J. Lubomirski. Warszawa 1863.

22. Kodeks Dyplomatyczny Małopolski, t. 1-2. Monumenta Medii Aevii Historica, t. 3-4. Wydał i przypisami objaśnił Dr Franciszek Piekosiński. Kraków 1876-1886.

23. Kodeks Dyplomatyczny Wielkopolski... Wydany staraniem Towarzystwa Przyjaciół Nauk Poznańskiego, t. 1-3. Poznań 1877-188i.

24. Kronika Marcina Galla przełożona na język polski i objaśnionà przez Z. Komarnickiego. Warszawa 1873.

M.

25. Mansi J. D., Sacrorum conciliorum nova et amplissima collectio, t. $1-3,6,8-11,13-14,20-24$ i 34. Paris et Leipzig 1901-1903.

26. Migne J. P., Patrologiae cursus completus, Patrologia graeca, t. 620 , 36, 67 i 82. Parisiis 1859-1894.

27. Migne J. P., Patrologiae cursus completus. Partologia Latina, t. 22, $54,66,107,119,125,126,131$ i 138 , Parisiis $1845-1853$.

N.

28. Najdawniejsze statuty synodalne archidiecezji gnieźnieńskiej oraz statuty z rękopisu Oss. $\mathrm{Nr} 1627 \mathrm{z}$ uwzględnieniem materiałów zebranych przez śp. B. Ulanowskiego. Opracował Wradysław Abraham. Kraków 1920.

29. Najstarsze statuty synodalne krakowskie biskupa Nankera z 2 października 1320 r. Wydał X. Dr Jan Fijałek. Kraków 1915.

P.

30. Peltier l'abbé, Dictionnaire universel et complet des conciles t. $\mathbf{1} \mathbf{- 2}$. Paris 1846-1847.

R.

31. Reformationes Generales ad Clerum et populum Dioecesis Cracovien. pertinentes. Ab... D. Martino Szyszkowski... Episcopo Grac. Duce Sever. in Synodo Diocesana sancitae et promulgatae A. 1621 die decima Februar. Crac. In Officina Andreae Petricovii Typogr. S. R. M. (Cyt. Ref. Gen.)

32. Statuta Noua Inclite prouintie Gnesnen. tempore felicis presidencie Reuerendissimi in Christo patris et domini Joannis de Lasko Sancte Ecclesie Gnesnen. Archiepiscopi primatis Legatique IVati, de consensu Omnium Reuerendissimorum dominorum coepiscoporum. 
et totius cleri. in diuersis prouincialibus Sinodis: confecta et aprobata. (na końcu) Excussum Cracouiae In Vigilia Sancti Stanislai. Anno domini Incarnationis, MDXXVIII(1528). Per Mathiam. Scharffenberg. expensis prouidi viri Marci Scharffenberg. Ciuis ac Biblipole Cracouien. Laus Deo. (Cyt. Zbiór Laskiego z 1528 r.).

33. Statuta Synodalia Dioecesana Sanctae Ecclesiae Vratislaviensis edidit M. de Montbach ... Secunda editio. Vratislaviae A. D. $185 \overline{5}$.

34. Statuta Synodalia Dioecesis Orthodoxae Kijoviensis Publicata Ab... D. Josepho Andrea Comite In Załuskie Junosza Załuski Episcopo Kijoviense et Cerniechoviense... Opus Primum Impressum In erecto noviter Typographeo Culmae in Prussia 1764.

35. Statuta Synodalia Dioecesis Wladislaviensis et Pomeraniae collegit et edidit Zeno Chodyński ... Varsaviae 1890.

36. Statuta toti provinciae gnesnensi valentia, condita praeside Nicolao II. Trąba Archiepiscopo Vieluno - Calissiensi A. 1420. Starodawne Prawa Polskiego Pomniki, t. 4, s. 173-261. Wyd. U. Heyzmann. Kraków 1875.

37. Statuty synodalne wieluńsko_kaliskie Mikołaja Trąby z. r. 1420 z materiałów przysposobionych przez B. Ulanowskiego uzupełnili i wydali X. Jan Fijałek i Adam Vetulani. Nakł. PAU Kraków $1915-1920-1951$.

38. Synodus Archidioecesana Gnesnensis praesidente Stanislao Karnkowski ... Lovicii Anno Domini 1583 celebrata nec non Articuli Alterius Synodi eiusdem Doecesis sub Jacobo Uchański Archiepiscopo habitae nunc primum ex Archivo Ven. Capituli Cathedr. Vladislavien. Zeno Chodyński ... edidit. Varsaviae 1872.

39. Synodus Diaecensana Chełmensis ab... D. Cristophoro Joanne in Słupow Szembek ... Epo Chełmensi, Nominato Premisliensi, Praeposito Generali Miechoviensi, Crasnostaviae, in Esia Cathedrali. Praesente Universo Dioecensis Clero Celebrata Die 18 Menisis Julit; et aliis duabus sequentibus diebus. A. D. 1717. Zamoscii, Typis Universitatis.

40. Theiner A., Vetera monumenta Poloniae et Lithuaniae. Poznań $1860-1861$, t. $1-2$.

U.

41. Ulanowski B., Acta Capituli Plocensis ab an. 1514 ad an. 1577. Odbitka z t. 10 Archiwum Kom. Histor. Kraków 1915.

42. Ulanowski B., Acta Capitulorum Cracoviensis et Plocensis. Odbitka. z t. 6 Archiwum Kom. Histor. Kraków 1891.

43. Ulanowski B., Acta Capitulorum nec non Iudiciorum ecclesiasticorum, t. 1. Monumenta Medii Aevi Historica, t. 13. Kraków 1894. 
44. Ulanowski B., Acta Capitulorum nec non Iudiciorum ecclesiasticocorum selecta, vol. 3, pars I. Monumenta Medii Aevi Historica, t. 18. Kraków 1908.

45. Ulanowski B., Analecta ad historiam iuris canonci in dioecesi Premisliensi. Archiwum Kom. Histor., t. 5, s. 359-436. Kraków 1889.

46. Ulanowski B., Materiały do historii ustawodawstwa synodalnego w Polsce w w. XVI. Archiwum Komisji Prawniczej, t. 1, s. 325-556 . Kraków 1895.

V.

47. Vita S. Stanislai Episcocopi Cracoviensis (vita minor) w opracowaniu Dr Wojciecha Kętrzyńskiego. Monumenta Poloniae Historica, t: s, s. 238-285, Lwów 1884.

\section{OPRACOW A I A}

A.

1. Abraham W., Gniezno i Nagdeburg. Kraków 1921.

2. Abraham W., Jedyne polskie biskupstwo przed rokiem 1000. Życie i Myśl 1950, z. 1/2, s. 33-44.

3. Abraham W., Organizacja Kościola w Polsce do polowy w. XII. Lwów 1908.

4. Amanieu A. Archiprêtre. Dictionnaire de droit canonique... publié sous la direction de R. Naz. Paris - VI 1935, t. 1, kol. 1004-1025.

B.

5. Bar. J. i Zmarz W., Polska bibliografia prawa kanonicznego od wynalezienia druku do 1940 r. T. 2 za lata 1800 -1940. Lublin 1947. Tow. NKUL.

6. Baran C. C., Sprawy narodowościowe u Franciszkanów Sląskich. Warszawa, 1954.

7. Barbosa A., Iuris ecclesiastici universi libri tres. Lugduni 1645 , t. 1 .

8. Benedictus XIV, De Synodo Dioecesana. Romae 1767.

9. Biskupski S., Krzysztof Źórawski - Polski kanonista XVIII stulecia. Włocławek 1950.

10. Buczek K., Pierwsze biskupstwa polskie. Kwartalnik historyczny 52(1938), s. 169-209. 
C.

11. Cance A., Le code de droit canonique. Paris 19246 , t. 1.

12. Cappello F. M. Summa iuris canonici. Romae $1945^{4}$.

13. Cocchi G., Commentarium in Codicem Iuris Canonici. Taurinorum Augustae 1940 4, t. 2.

14. Czaplewski P., Tytularny episkopat w Polsce średniowiecznej (bez miejsca wydania i daty).

E.

15. Encyklopedia kościelna ... Wydana przez X. Michała Nowodworskiego, t. $1-4,11-12,14,20,23,25,27-28,31$ i 33 . Warszawa $1873-$ -1933 .

F.

16. Ferraris F. L., Bibliotheca. Romae 1885, t. 1.

G.

17. Grabowski I., Prawo kanoniczne. Lwów 1927.

18. Grabowski I., Prawo kanoniczne. Warszawa 19484.

19. Gravina J. V., Institutiones canonicae. Varsaviae ad S. Crucem 1821.

20. Gromnicki T., Synody prowincjonalne oraz czynności niektórych funkcjonariuszów apostolskich $\mathrm{w}$ Polsce do roku 1357. Kraków 1885.

I.

21. Iuris ecclesiastici analysis. Pars prior. Vratislaviae 1795. Typis Universitatis.

K.

22. Korytkowski J., Arcybiskupi gnieźnieńscy, prymasowie i metropolici polscy od 1000 roku aż do 1821 roku, czyli do połączenia arcybiskupstwa gnieźnieńskiego $z$ biskupstwem poznańskim. Poznań 1888, t. 2.

23. Krynicki W., Dzieje kościoła powszechnego. Opracował O. Władysław Szoìdrski CSSR. Wlociawek 1930-1931 2 $_{2}$ t. $1-2$.

24. Kujot S., Dzieje Prus Wschodnich, Torun 1913.

25. Kujot S., Kto założył parafie w dzisiejszej diecezji chelmińskiej. Toruń 1903.

26. Kurtscheid B., Historia iuris canonici. Historia institutionum. Romae 1941 , t. 1.

27. Kutrzeba S., Historia źródeł dawnego prawa polskiego. Lwów - Warszawa - Kraków 1926, t. 2.

L.

28. Laurentius J., Institutiones iuris ecclesiastici. Friburgi Brisgoviae 1908. 
E.

29. Eaguna S., Pierwsze wieki Kościoła polskiego. Kwartalnik Histo. ryczny 5(1891). s. 549-568.

M.

30. Mratthaeus Conte a Coronata. Institutiones iuris canonici. Torino 19473 , t. 1.

31. Makowski J., Prawo międzynarodowe. Warszawa 1919.

O.

32. O początku władzy dziekanów foralnych. Archiwum Teologiczne $1(1836)$, s. $152-166$.

P.

33. Podręczna Encyklopedia Kościelna. Opracowana pod kierunkiem ... redaktora Ks. Zygm. Chełmickiego, t. 1-2, 5-6, 7-8, 15-16, 25$-26,33-34,37-40$. Warszawa 1904-1914.

34. Przybylko M., Urząd dziekana w polskim ustawodawstwie synodalnym XVIII w. (maszynopis).

R.

35. Reiffenstuell A., Ius canonicum universum. Parisiis 1853, t. I.

36. Rostworowski J., Charakter i znaczenie biskupstwa $w$ pierwszych đwóch wiekach dziejów Kościoła. Kraków 1925.

S.

37. Santi F., Praelectiones iuris canonici. Ratisbonae 1886 t. 1.

38. Sawicki J., Synody diecezji łuckiej i ich statuty. Concilia Poloniae, t. 3. Warszawa 1949. Tow. NW.

39. Silnicki T., Dzieje i ustrój Kościoła katolickiego na Sląsku do końca w. XIV. Warszawa 1953. Wyd. „Pax".

40. Silnicki T., Organizacja archidiaconatu w Polsce, Lwów 1927.

41. Schmalzgrueber F., Ius ecclesiasticum universum. Romae 1844, t. $1_{3}$ cz. 2.

42. Szcześniak W., Dzieje Kościoła katolickiego. Warszawa 1902, t. 1.

T.

43. Thomassinus L., Vetus et nova Ecclesiae dlisciplina circa beneficia et beneficiarios. Iagontiaci 1787, t. 1, ks. 2.

Prawo Kanoniczne -10 
V.

44. Vetulani A., $\mathrm{Z}$ badań nad znajomościa powszechnego prawa kanonicznego w Polsce w XIII wieku. Warszawa (bez daty).

W.

45. Wernz. F., Ius Decretalium. Romae 1899, t. 2.

46. Wernz-Vidal, Ius canonicum ad Codicis normam exactum. Romae 1928 , t. 2.

$\mathrm{Z}$.

47. Zachorowski S., Jakób biskup płocki i jego działalność ustawodawcza i organizacyjna 1396-1425. Kraków 1915. AU.

48. Zachorowski S., Początki parafii polskich. Kraków 1908.

49. Zachorowski S., Rozwój i ustrój kapituł polskich w wiekach średnich. Kraków 1912.

50. Zachorowski S., Sądy synodalne w Polsce. Odbitka z t. 54 rozpraw Wydziału hist.-filoz. Akad. Umiej. w Krakowie. Kraków 1911. AU. 


\section{SPIS TRESCI}

(Prawo Kanoniczne R. $1960 \mathrm{Nr} 3-4$ )

Wstep

Rozdział I. Etymologiczne i rzeczowe znaczenie pojęcia dziekana [ 5]

Rozdział II. Chorepiskopi

1. Dzieje urzędu biskupów wiejskich . . . . . . . [10]

A. Na Wschodzie . . . . . . . . . . . . [10]

B. Na Zachodzie . . . . . . . . . . . . . [16]

2. Uprawnienia . . . . . . . . . . . . . . . . [21]

Rozdzial III. Wizytatorzy . . . . . . . . . . . [22]

Rozdział IV: Archidiakoni . . . . . . . . . . . [24]

1. Archidiakoni w powszechnym prawie kościelnym . . . [24]

A. Archidiakon jednostkowy . . . . . . . . . [24]

a. Powstanie urzędu . . . . . . . . . . . . . . [24]

k. Uprawnienia . . . . . . . . . . . . . [27]

B. Archidiakoni okregowi . . . . . . . . . . [ [30]

a. Powstanie urzędu . . . . . . . . . . . . [30]

๖. Uprawnienia . . . . . . . . . . . . . . [33]

๖. Ograniczenie władzy . . . . . . . . . . [36]

C. Zagadnienie archiđiakonów na Wschodzie . . . . [40]

2. Archidiakoni $w$ polskim prawie kościelnym . . . . . [40]

A. Archidiakon jednostkowy . . . . . . . . [40]

a. Archidiakon gnieźnieński Galla . . . . . . [40]

b. Archidiakon jednostkowy w pozostałych diecezjach polskich . . . . . . . . . . . . . [44]

B. Archidiakoni okręgowi . . . . . . . . . . [49]

a. Powstanie urzędu . . . . . . . . . . . . . . $[49]$

๖. Uprawnienia . . . . . . . . . . . [58]

c. Ograniczenie władzy . . . . . . . . . [76]

(Prawo Kanoniczne R. $1962 \mathrm{Nr}$ 1-2)

Rozdzial V. Archiprezbiterzy . . . . . . . . . . . [79]

1. Archiprezbiterzy w powszechnym prawie kościelnym . . [79]

A. Archiprezbiter jednostkowy . . . . . . . . [79]

a. Powstanie urzędu . . . . . . . . . . . . . [79]

b. Uprawnienia . . . . . . . . . . . . [81]

c. Ograniczenie władzy . . . . . . . . . . . [86] 
B. Archiprezbiterzy okręgowi - dziekani . . . . . [ 88]

a. Powstanie urzędu i pierwotne jego uprawnienia . [ 88]

b. Rozwój uprawnień . . . . . . . . . . . [ 95]

c. Ograniczenie władzy . . . . . . . . . [106]

2. Archiprezbiterzy okręgowi, czyli dziekani w polskim prawie kościelnym : . . . . . . . . . . . . . [115]

A. Powstanie i rozwój urzędu dziekańskiego . . . . [115]

B. Upadek i odrodzenie instytucji dziekanatu . . . . [133]

Zakończenie . . . . . . . . . . . . [139]

Wykaz źródeỉ i opracowań . . . . . . . . [141] 